\title{
The Neuropsychopharmacology of Phencyclidine: From NMDA Receptor Hypofunction to the Dopamine Hypothesis of Schizophrenia
}

\author{
J. David Jentsch, Ph.D., and Robert H. Roth, Ph.D.
}

\begin{abstract}
Administration of noncompetitive NMDA/glutamate receptor antagonists, such as phencyclidine $(P C P)$ and ketamine, to humans induces a broad range of schizophrenic-like symptomatology, findings that have contributed to a hypoglutamatergic hypothesis of schizophrenia. Moreover, a history of experimental investigations of the effects of these drugs in animals suggests that NMDA receptor antagonists may model some behavioral symptoms of schizophrenia in nonhuman subjects. In this review, the usefulness of PCP administration as a potential animal model of schizophrenia is considered. To support the contention that NMDA receptor antagonist administration represents a viable model of schizophrenia, the behavioral and neurobiological
\end{abstract}

effects of these drugs are discussed, especially with regard to differing profiles following single-dose and long-term exposure. The neurochemical effects of NMDA receptor antagonist administration are argued to support a neurobiological hypothesis of schizophrenia, which includes pathophysiology within several neurotransmitter systems, manifested in behavioral pathology. Future directions for the application of NMDA receptor antagonist models of schizophrenia to preclinical and pathophysiological research are offered. [Neuropsychopharmacology 20:201-225, 1999] (C) 1999 American College of Neuropsychopharmacology. Published by Elsevier Science Inc.
KEY WORDS: Ketamine; Phencyclidine; Psychotomimetic; Memory; Catecholamine; Schizophrenia; Prefrontal cortex; Cognition; Dopamine; Glutamate

Biological psychiatric research has seen the development of many putative animal models of schizophrenia. The etiological bases of these models have varied

From the Neuropsychopharmacology Research Unit (JDJ, RHR), Section of Neurobiology (JDJ), and Departments of Psychiatry (RHR) and Pharmacology (RHR), Yale University School of Medicine, New Haven, Connecticut.

Address correspondence to: Dr. J. David Jentsch, Section of Neurobiology, Yale University School of Medicine, P.O. Box 208001, New Haven, Connecticut 06520-8001.

Received 25 March 1998; revised 22 May 1998; accepted 13 June 1998. widely from the administration of purportedly psychotomimetic drugs (Snyder 1988; Javitt and Zukin 1991; Jentsch et al. 1998a), to perinatal insults (Lipska et al. 1993; El-Khodor and Boksa 1997; Moore and Grace 1997; Bertolino et al. 1997), to chronic social isolation or stress (Jones et al. 1990), and beyond. The administration of psychotomimetic drugs to humans and animals represents probably the most widely accepted and utilized class of schizophrenia models. These "pharmacological" models seem to represent methods for the induction of psychopathology in humans and aberrant (potentially related) behavior in animals.

At the behavioral level, there seems to be some heterogeneity in the effects of different psychotomimetic drug classes. The psychomotor stimulants, such as amphetamine and cocaine, can clearly induce a form of 
paranoid psychosis in human subjects after high-dose or long-term administration, but evidence regarding the ability of these agents to induce "deficit" state symptoms is conflicting (Angrist and Gershon 1970; Everitt et al., 1997); moreover, there is evidence that amphetamine may actually alleviate negative and cognitive symptoms in schizophrenic patients (Angrist et al. 1982; Goldberg et al. 1991; Carter et al. 1997). Psychotomimetic indoleamines, such as lysergic acid diethylamide, can induce profound sensory hallucinations without causing any apparent deficit state in normal subjects (Geyer and Markou 1994) and without precipitating symptomatology in schizophrenic patients (Cohen et al. 1962). In contrast, the noncompetitive antagonists of the $\mathrm{N}$-methyl-D-aspartate (NMDA)/glutamate receptor, including phencyclidine (PCP) and ketamine, seem to be capable of inducing both positive and negative symptoms of schizophrenia, including cognitive dysfunction in normal humans (Snyder 1980; Javitt and Zukin 1991; Tamminga 1998); these drugs also profoundly exacerbate both positive and negative symptoms in schizophrenic patients (Itil et al. 1967; Lahti et al. 1994; Malhotra et al. 1997a).

Because of the more comprehensive psychopathology induced by PCP, many researchers have studied the effects of NMDA receptor antagonists in humans and animals to gain insights into the neurobiology of schizophrenia. In this review, the validity of NMDA receptor antagonist-induced models of schizophrenia in humans and animals are considered, and the applicability of acute versus chronic administration of PCP as a more precise model is assessed. The neurobiological substrates of the observed behavioral effects in acute and chronic NMDA receptor antagonist models are reviewed. Finally, new directions for use of PCP/ketamine administration as a model of schizophrenia are offered.

\section{BASIS OF THE PCP/KETAMINE MODELS OF SCHIZOPHRENIA IN HUMANS}

Nearly 40 years ago, it was first reported that acute administration of the noncompetitive NMDA-sensitive glutamate receptor antagonist PCP to normal humans induced a psychopathology with "impressive similarity [to] . . . certain primary symptoms of the schizophrenic process" (Luby et al. 1959, p. 367). This finding has been replicated over the intervening years (Davies and Beech 1960; Cohen et al. 1962), and in addition, it has been found that PCP likewise exacerbates the primary symptoms of chronic schizophrenic patients (Luby et al. 1959; Itil et al. 1967).

Controlled studies of the effects of PCP in normal and schizophrenic humans are now prohibited, in part, because of the overtly neurotoxic effects of this drug as determined by studies in rodents (Olney et al. 1989; 1991; Olney and Farber 1995). Nevertheless, scientists have recently utilized a PCP congener, ketamine, to produce a model of psychosis in humans. This drug, which (like PCP) noncompetitively blocks NMDA receptors, also simulates schizophrenic psychopathology in normal humans (Krystal et al. 1994; Malhotra et al. 1996) and exacerbates symptoms in schizophrenic patients (Lahti et al. 1994; Malhotra et al. 1997a). Although it seems that ketamine can induce many of the effects of PCP in humans, it should be noted that ketamine is far less potent for inducing psychotomimetic reactions, especially after chronic use (Rainey and Crowder 1974). Several reports have demonstrated that competitive NMDA receptor antagonists are also psychotomimetic in humans (Bunney et al. 1994; Grotta et al. 1995; Tamminga 1998).

It is important to summarize the primary symptoms of schizophrenia that may be "modeled" in a drugtreated individual. Many of the "positive" symptoms of schizophrenia, including paranoia, hallucinations, impulsivity, formal thought disorder, delusions, and violent behavior, are characteristic of psychotomimetic drug-induced psychopathology (Angrist and Gershon 1970; Javitt and Zukin 1991; Ellison 1995), but PCP seems to be unique among psychostimulants because of its ability to produce "negative" or deficit state symptoms of schizophrenia, such as emotional lability and social withdrawal. In addition, PCP/ketamine administration can lead to profound cognitive dysfunction (Luby et al. 1959; Cohen et al. 1962; Pearlson 1981; Javitt and Zukin 1991), including impaired performance of the Wisconsin Card Sort and continuous performance vigilance tasks and deficits in delayed recall, free recall, recognition memory, and verbal fluency (Krystal et al. 1994; Malhotra et al. 1996). Many of these deficits implicate frontal lobe dysfunction (Krystal et al. 1994), which is critical for the validity of a PCP model of schizophrenia, because frontal cortical deficits are clearly a component of the schizophrenic disease process (Fey 1951; Robbins 1990; Goldman-Rakic 1991; Weinberger and Berman 1996; Goldman-Rakic and Selemon 1997).

Although the initial observations of NMDA receptor antagonist-induced psychosis were made in humans in small, controlled studies of the effects of single-dose exposure, PCP became a popular drug-of-abuse within certain subcultures by the early 1960s. In addition to the "toxic psychosis" induced by single-dose administration, it has also been noted that repeated use of PCP by humans induces a more persistent schizophrenic symptomatology, including psychosis, hallucinations, flattened affect, delusions, formal thought disorder, cognitive dysfunction, and social withdrawal (Rainey and Crowder 1975; Allen and Young 1978; Pearlson 1981; Javitt and Zukin 1991; Cosgrove and Newell 1991). 


\section{DO ACUTE AND LONG-TERM PCP EXPOSURE HAVE SIMILAR CONSEQUENCES?}

An important question pertains to whether the difference between the behavioral and biological effects of acute and chronic PCP exposure are more real than apparent. As already noted, both regimens can induce profound behavioral symptomatology reminiscent of schizophrenia in humans, but there are more differences between the consequences of acute versus longterm PCP administration than merely the duration of the observed effects.

Table 1 summarizes the reported effects of acute and long-term PCP/ketamine exposure in humans. Both regimens can induce psychosis, thought disorder, delusions, flattened affect, and withdrawal, with the effects of chronic exposure being generally more persistent (Luby et al. 1959; Rainey and Crowder 1975; Allen and Young 1978; Pearlson 1981; Krystal et al. 1994; Malhotra et al. 1996). The quantitative differences in the time course of the effects of the two regimens may be largely attributable to differences in dosage and route of administration. Studies have rarely controlled for these factors. What is interesting is that there are qualitative differences between the effects of these two dosing regimens. Acute ketamine administration produces delusions and hallucinations, typically within the visual domain (Krystal et al. 1994), similar to LSD intoxication but not to schizophrenia (Geyer and Markou 1994). More consistent with symptoms observed in schizophrenic patients, PCP-abusing humans present with religious and paranoid delusions and auditory hallucinations (Rainey and Crowder 1975; Allen and Young 1978). In addition, long-term PCP abuse is associated with "emotional lability, social incompetence, overt impulsiveness, poor social judgment, poor attention span and concentration, poor interpersonal relationships, and social maladjustment" (American Psychiatric Association 1989, p. 1217). These findings provide support for the argument that long-term PCP abuse is associated with a psychopathology that is remarkably similar to schizophrenia and that may be more isomorphic to the chronic symptoms of schizophrenia (e.g., cognitive and negative symptoms) than those induced by single-dose PCP exposure.

Other differences lie in the biological effects of PCP. Recent studies of regional cerebral blood flow after ketamine or PCP administration may provide clues as to the neural circuits affected by NMDA receptor antagonist administration in humans. Acute ketamine exposure markedly increases frontal cortical blood flow, especially in the anterior cingulate and frontomedial cortical regions of normal humans or schizophrenic patients (Lahti et al. 1995; Breier et al. 1997a; Vollenweider et al. 1997). In sharp contrast, long-term abuse of PCP by humans has been associated with reduced frontal lobe blood flow and glucose utilization (Hertzman et al. 1990; $\mathrm{Wu}$ et al. 1991). The finding that repeated exposures to PCP reduces frontal blood flow is consistent with the observation that some components of the cognitive dysfunction of schizophrenia are associated with reduced frontal blood flow, so-called "hypofrontality" (Ingvar and Franzen 1974; Weinberger et al. 1986; Andreasen et al. 1992; Weinberger and Berman 1996). Thus, long-term, but not acute, PCP exposure isomorphically models the behavioral and metabolic dysfunction of schizophrenia.

Likewise, previous studies have clearly shown that acute administration of PCP or ketamine to animals profoundly increases forebrain dopaminergic transmission (Doherty et al. 1980; Bowers and Hoffman 1984;

Table 1. Differing Psychiatric and Biological Effects of Acute versus Long-Term PCP/ Ketamine Exposure in Humans

\begin{tabular}{|c|c|c|}
\hline & Acute Exposure & Repeated Exposures \\
\hline Psychosis & Intense (hours) ${ }^{a, b}$ & Intense (days to weeks) ${ }^{c, d}$ \\
\hline Hallucinations & Visual illusions (hours) ${ }^{b}$ & $\begin{array}{l}\text { Auditory and paranoid } \\
\text { (days to weeks) }^{d}\end{array}$ \\
\hline Delusions & Yes (hours) ${ }^{a, b}$ & $\begin{array}{l}\text { Frequently religious } \\
\quad \text { (days to weeks) }^{d}\end{array}$ \\
\hline Thought disorder & Yes (hours) $)^{a, b}$ & Yes (days to weeks) ${ }^{c, d}$ \\
\hline Affect & Euphoric to catatonic (hours) ${ }^{a, b}$ & $\begin{array}{l}\text { Anxious, labile or paranoid } \\
{\text { (days to weeks) }{ }^{d}}^{\text {days }}\end{array}$ \\
\hline Cognition & Impaired (transiently) ${ }^{b}$ & Impaired (persistently) ${ }^{e}$ \\
\hline Frontal blood flow & Increased (transiently) ${ }^{f}$ & Decreased (persistently) ${ }^{g}$ \\
\hline
\end{tabular}

\footnotetext{
${ }^{a}$ Luby et al. (1959).

${ }^{b}$ Krystal et al. (1994).

${ }^{c}$ Rainey and Crowder (1975).

${ }^{d}$ Allen and Young (1978).

${ }^{e}$ Cosgrove and Newell (1991).

${ }^{f}$ Breier et al. (1997a).

${ }^{8}$ Hertzman et al. (1990).
} 
Deutch et al. 1987; Hertel et al. 1996; Verma and Moghaddam 1996; Jentsch et al. 1997a); whereas, longterm PCP administration reduces frontal dopamine transmission (Jentsch et al. 1997b,c; see below). Because hypofrontality and some cognitive deficits of schizophrenia have been associated with reduced dopamine transmission within the prefrontal cortex (Weinberger et al. 1988; Daniel et al. 1989, 1991; Dolan et al. 1995; reviewed in Davis et al. 1991; Knable and Weinberger 1997), these findings suggest that long-term administration of NMDA receptor antagonists produces effects that are most consistent with schizophrenia. Later in this review, the validity of acute versus long-term PCP exposure as models of schizophrenia is revisited.

\section{THE RELATIVE VALIDITY OF ANIMAL MODELS OF SCHIZOPHRENIA}

Studies of the neurochemical effects of PCP in animals, in part, represent the trend to utilize these drugs in nonhuman subjects to model aspects of idiopathic schizophrenia. These animal studies may provide new insights regarding the pathophysiology and treatment-responsivity of schizophrenia without the ethical and pragmatic constraints associated with using human experimental subjects. Nevertheless, an insurmountable obstacle is the inability to model certain schizophrenic deficits (e.g., those associated with verbal behavior) in animals, making it impossible to produce a comprehensive model of schizophrenia in nonhuman subjects. Despite these obvious limitations, animal models may be able to reflect subsets of primary behavioral symptoms of schizophrenia; for example, frontal-like cognitive dysfunction. Likewise, it may be possible to mimic certain biological sequelae of schizophrenia (e.g., "hypofrontality"; Weinberger and Berman 1996) in a model system (e.g., human PCP abusers, Hertzman et al. 1990).

Another important consideration in determining the comprehensive validity of a particular animal model of schizophrenia is that the idiopathic disease likely represents a conglomeration of numerous behavioral, etiological, and pathophysiological factors. As such, a single model system may be incapable of representing all symptoms of schizophrenia reliably or comprehensively. This possibility makes the prospect of multiple, heterogeneous animal models a tantalizing one, because different systems may confer particular insights regarding differing classes of symptoms of schizophrenia.

The problems associated with developing a model of schizophrenia with comprehensive face validity, let alone construct validity, seem daunting. Nevertheless, as noted by Geyer and Markou (1994) in their review of this subject, it is most important to develop and utilize model systems that: (1) exhibit some symptomatic iso- morphism with the idiopathic disease; (2) present with dependent measures that can be objectively quantified; and (3) are reproducible and robust. These features can confer a particular model with characteristics sufficient to yield a pragmatically acceptable level of validity. A final, and perhaps most critical, consideration is the predictive validity of a particular model. Can the model yield new and predictive insights regarding novel treatment strategies? Again, it is important to limit the interpretation of any data within the context that a particular model system may only mimic a particular domain of symptoms and is not likely predictive of the comprehensive response of a human patient to a given treatment.

The PCP/ketamine model of schizophrenia seems to be valid at several levels of interpretation. Clearly, PCP or ketamine administration induces behavioral pathologies in humans that are isomorphic to certain primary symptoms of schizophrenia, which are readily quantifiable and highly robust; for example, frontal-like cognitive dysfunction (Luby et al. 1959; Javitt and Zukin 1991; Krystal et al. 1994). In addition, this model system may have demonstrable predictive validity, because ketamine-precipitated psychosis has been shown to be responsive to the atypical antipsychotic drug clozapine (Malhotra et al. 1997a). Finally, mounting data in nonhuman primates (see below) suggests that, in animals, PCP may have strong face and construct validity for schizophrenia. Thus, in the following sections, we focus our discussion on many of the findings of the behavioral and biological consequences of PCP administration in animals.

\section{NMDA ANTAGONIST-INDUCED BEHAVIORAL ALTERATIONS IN ANIMALS: ISOMORPHISM TO SCHIZOPHRENIA?}

Many attempts have been made to draw parallels between the behaviors exhibited by (acute and chronic) PCP-treated animals and schizophrenic symptomatology (see Geyer and Markou 1994; Steinpreis 1996; Jentsch et al. 1998a for review). The quantified behaviors examined occur within several different domains, including locomotor behavior, sensorimotor gating, cognitive function, motivation, and social behavior. The behavioral effects of PCP administration (both after acute and long-term administration) are summarized in Table 2.

\section{Effects of Acute PCP Administration on Noncognitive Behavior}

Several groups have studied the ability of acute administration of $\mathrm{PCP}$, or its congeners, to stimulate locomotor behavior in animals (Freed et al. 1980; Carlsson 
1988; Carlsson and Carlsson 1989; Boyce et al. 1991; Moghaddam and Adams 1998). This is based upon the notion that "locomotor activity in the rodent may be a useful indicator of the propensity of a drug to elicit or exacerbate psychosis in humans ..." (p. 1350) (Moghaddam and Adams 1998); however, the relationship between rodent locomotor behavior and schizophrenic symptoms lacks "discriminant validity" because several drugs which stimulate locomotion in rats (e.g., alpha-2 antagonists and nicotine) fail to produce or elicit psychosis in humans (Levin et al. 1996; Glazer et al. 1987). In contrast, delta-9-tetrahydrocannabinol can produce or precipitate psychosis in normal and schizophrenic humans, respectively, (D'Souza et al. 1997), yet is cataleptic in rodents. Nevertheless, dysfunction within corticostriatal-pallido-thalamo-cortical loops produced by PCP administration may contribute to both locomo- tor abnormalities in PCP-treated rats (Carlsson and Carlsson 1989) and in schizophrenia (Robbins 1990; Grace and Moore 1998).

Single-dose PCP administration to rats has also been shown to disrupt prepulse inhibition, a measure of sensorimotor gating (Geyer et al. 1984), a finding with isomorphism to startle-gating deficits of schizophrenic patients (Geyer and Braff 1987; Braff et al. 1992). In this paradigm the delivery a stimulus that normally causes startle in animals or humans (a mild shock or very loud tone) is presaged by a neutral stimulus. In normal humans and animals, the delivery of the neutral stimulus results in reduced startle. In contrast, PCP-treated animals and schizophrenics both exhibit an inability to attenuate their startle response with the presentation of the neutral "warning" stimulus. The face validity of the prepulse inhibition paradigm for modeling schizo-

Table 2. Effects of Acute versus Long-Term Exposure to PCP on Rodent and Primate Behavior

\begin{tabular}{|c|c|c|}
\hline & Acute Exposure & Repeated Exposures \\
\hline \multicolumn{3}{|l|}{ Rodent } \\
\hline Frontal cortex function & Impaired $^{a}$ & Impaired $^{b}$ \\
\hline Temporal cortex function & Impaired $^{d-h}$ & Preserved $^{c}$ \\
\hline Sensorimotor gating & Impaired $^{i}$ & Unknown \\
\hline Motor function & Impaired $^{j}$ & Preserved $^{b}$ \\
\hline Motivation & Impaired $^{k-o}$ & Preserved $^{b}$ \\
\hline Associative processes & Impaired $^{k-o}$ & Preserved $^{c}$ \\
\hline Social behavior & Reduced $^{p}$ & Reduced $^{p}$ \\
\hline Locomotion & Increased $^{q}$ & $\begin{array}{l}\text { Augmented response to stress } \\
\text { or amphetamine }{ }^{r}\end{array}$ \\
\hline \multicolumn{3}{|l|}{ Nonhuman primate } \\
\hline Frontal cortex function & Impaired $^{s}$ & Impaired $^{t}$ \\
\hline Temporal cortex function & Impaired $^{u}$ & Unknown \\
\hline Motor function & Impaired $^{v}$ & Preserved $^{t}$ \\
\hline Motivation & Impaired $^{v}$ & Preserved $^{t}$ \\
\hline Social behavior & Reduced $^{w}$ & Unknown \\
\hline Locomotion & Typically reduced $^{c}$ & $\begin{array}{l}\text { Increased locomotion and } \\
\text { stereotypy in some cases }\end{array}$ \\
\hline \multicolumn{3}{|l|}{${ }^{a}$ Verma and Moghaddam (1996). } \\
\hline \multicolumn{3}{|l|}{${ }^{b}$ Jentsch et al. (1997b). } \\
\hline \multicolumn{3}{|l|}{${ }^{c}$ Our unpublished observations. } \\
\hline \multicolumn{3}{|l|}{${ }^{d}$ Heale and Harley (1990). } \\
\hline \multicolumn{3}{|l|}{${ }^{e}$ Jones et al. (1990). } \\
\hline \multicolumn{3}{|l|}{${ }^{f}$ Kesner and Davis (1993). } \\
\hline \multicolumn{3}{|l|}{${ }^{g}$ Murray and Ridley (1997). } \\
\hline \multicolumn{3}{|l|}{${ }^{h}$ Fraser et al. (1997). } \\
\hline \multicolumn{3}{|l|}{${ }^{i}$ Geyer et al. (1984). } \\
\hline \multicolumn{3}{|l|}{${ }^{j}$ Tricklebank et al. (1989). } \\
\hline \multicolumn{3}{|l|}{${ }^{k}$ Hoehn-Saric et al. (1991). } \\
\hline \multicolumn{3}{|l|}{${ }^{l}$ Aguado et al. (1994). } \\
\hline \multicolumn{3}{|l|}{${ }^{m}$ Pallares et al. (1995). } \\
\hline \multicolumn{3}{|l|}{${ }^{n}$ Tang and Ho (1988). } \\
\hline \multicolumn{3}{|l|}{${ }^{\circ}$ Stevens et al. (1997). } \\
\hline \multicolumn{3}{|c|}{$p$ Sams-Dodd (1996). } \\
\hline \multicolumn{3}{|c|}{${ }^{q}$ McCullough and Salamone (1992). } \\
\hline \multicolumn{3}{|c|}{${ }^{r}$ Jentsch et al. (1998c). } \\
\hline \multicolumn{3}{|l|}{${ }^{s}$ Boyce et al. (1991). } \\
\hline \multicolumn{3}{|c|}{${ }^{t}$ Jentsch et al. (1997c) } \\
\hline \multicolumn{3}{|c|}{ " Moerschbaecher and Thompson (1980). } \\
\hline \multicolumn{3}{|c|}{${ }^{v}$ Frederick et al. (1995). } \\
\hline${ }^{w}$ Schlemmer and Davis (1983 & & \\
\hline
\end{tabular}


phrenic sensorimotor-gating deficits has been well established (Geyer and Markou 1994).

Acute PCP administration has also been shown to reduce social interactions in rats (Steinpreis et al. 1994; Sams-Dodd 1995, 1996) and monkeys (Miller et al. 1973; Schlemmer and Davis 1983). Although these effects seem to bear relationship to the social deficits exhibited by schizophrenic subjects, it would be informative to know whether these drug-induced effects occur independent of nonspecific alterations in general locomotion and arousal. Moreover, it is possible that rodent social/interactive behavior is a measure that has a problematic relationship with schizophrenic social withdrawal (i.e., the measured construct is not the same). It seems that deficits in social interactions in schizophrenic subjects are not a primary symptom of the disorder, per se, but rather, are secondary to a variety of other symptoms, such as cognitive dysfunction, flattened affect, primary thought disorder, impulsivity, and psychosis (Dickerson et al. 1996). Thus, care should be exercised when drawing parallels between the social dysfunction of schizophrenia and that of PCP-treated rodents.

\section{Effects of Acute PCP Administration on Cognitive Behavior}

Attempts to study cognitive functions in PCP-treated animals may yield the more informative results for several reasons. The performance of cognitive tasks by animals and humans may depend on similar neural and psychological constructs, and the validity of the particular tasks may be directly assessed. Second, measures of cognitive behavior in animals can be frankly objective, especially when automated testing or highly controlled task circumstances are used. Finally, much is known about the cognitive constructs subserved by particular brain regions (e.g., working memory function in prefrontal cortex; monkeys: Goldman-Rakic 1987; humans: Courtney et al. 1998), and a variety of behavioral tasks can be used to measure the same construct (e.g., delayed response, delayed nonmatch-tosample with repeated objects, $N$-back tasks, self-ordered tasks). Thus, different procedures can be used in humans and animals, if necessary, to measure similar constructs. In consideration of the above, we focus much of our subsequent discussion on cognitive functions in NMDA receptor antagonist-treated animals as models of schizophrenic cognitive dysfunction.

Many studies have examined the effects of acute NMDA receptor antagonist administration on cognitive functions. Although schizophrenia is certainly associated with fairly wide-ranging deficits, it is unclear whether the global impairments caused by PCP administration are comprehensively representative of schizophrenic deficits. Administration of PCP, ketamine, or
MK-801 (another noncompetitive NMDA receptor antagonist) to rats has been shown to impair performance on tasks that seem to depend upon hippocampal or amygdalar function; for example passive avoidance, acquisition of the Morris water maze task, or a conditional discrimination or performance of a spatial continuousrecognition memory task (Heale and Harley 1990; Jones et al. 1990; Kesner and Davis 1993; Murray and Ridley 1997). In addition, although delayed alternation deficits have been reported after ketamine and MK-801, suggesting spatial working memory dysfunction (Verma and Moghaddam 1996), spontaneous (no-delay) alternation is likewise affected (Fraser et al. 1997), complicating this interpretation. Furthermore, administration of noncompetitive NMDA receptor antagonists has been shown to impair even simple behavioral measures, such as acquisition of a conditioned emotional response (Hoehn-Saric et al. 1991), of a flavor aversion (Aguado et al. 1994), of an operant response (Pallares et al. 1995), of a brightness discrimination (Tang and Franklin 1983; Tang and Ho 1988), or of a conditioned cue preference (Stevens et al. 1997). Because many of these latter tasks depend largely upon simple sensory processes and associative learning (which are relatively preserved in schizophrenic patients), the specificity of "cognitive" deficits in animals acutely treated with $\mathrm{PCP} /$ ketamine/MK-801 is questionable. It is important to comment that acute PCP administration to monkeys similarly impairs performance of working memory tasks in a delay-independent fashion (Boyce et al. 1991; Hudzik and Wenger 1993), visual recognition tasks (Ogura and Aigner 1993), conditional discrimination tasks (Moerschbaecher and Thompson 1980), and tasks that measure motivation and other nonspecific effects (Frederick et al. 1995). Thus, care should be taken when arguing for complete isomorphism between acute NMDA receptor antagonist-induced behavioral deficits in animals and the symptoms of schizophrenia.

\section{Effects of Long-Term PCP Administration on Noncognitive Behavior}

As previously discussed, the effects of chronic, rather than acute, exposure to PCP may better represent some facets of schizophrenia. Thus, it is important to understand the behavioral/cognitive consequences of longterm exposure to PCP in animals. Although few investigators have explored the behavioral and cognitive deficits associated with chronic PCP administration, initial examinations (see below) suggest that a more selective set of impairments results from long-term dosing. Altered social behavior, locomotor sensitization, and cognitive function might be expected to be altered in chronic PCP-treated animals if the effects of PCP represent a possible model of schizophrenia. Social deficits have been reported in rats after cessation of long-term 
PCP administration (Steinpreis et al. 1994; Sams-Dodd 1995, 1996), although it is not presently clear how enduring these effects are.

Behavioral sensitization is a phenomenon whereby repeated exposures to a drug or environmental stimulus lead to progressively enhanced behavioral responses. A "sensitization" hypothesis of schizophrenia has been offered in an attempt to describe psychomotor stimulant-induced psychosis and stress-precipitated psychopathology (Robinson and Becker 1986; Post et al. 1988; Lieberman et al. 1997). PCP-induced sensitization of limbic circuits might have relevance to the neurobiology of schizophrenia, as sensitization to the locomotorstimulating effects of PCP, ketamine, and MK-801 has been reported (Scalzo and Holson 1992; Wolf and Khansa 1991; Xu and Domino 1994). Importantly, this phenomenon seems to be very dose and regimen sensitive and may be complicated by tolerance to the ataxic effects of PCP (Melnick et al. 1997).

Augmented locomotor responsivity to stress and $\mathrm{d}$-amphetamine has been reported after long-term PCP exposure (Jentsch et al. 1998c), and subchronic ketamine administration has been shown to increase apomorphine-induced stereotypy (Lannes et al. 1991). Furthermore, we have observed that subchronic PCP exposure leads to an increased mesolimbic dopamine response after an acute administration of haloperidol (Jentsch et al. 1998c). Therefore, at least a component of limbic circuitry (the mesolimbic dopamine system) does seem to show augmented function after long-term NMDA receptor antagonist exposure; however, it is not currently apparent that this is attributable to a simple sensitization phenomenon, because the locomotor response to PCP itself is reduced after the drug administration regimen used in our studies (Jentsch and Taylor, unpublished observations). Thus, although locomotor sensitization may yield some insights regarding subcortical dopaminergic hyperactivity, it may not be a prerequisite of this hyperactivity.

\section{Effects of Long-term PCP Administration on Cognitive Behavior}

Recently, the cognitive effects of long-term PCP treatment in rats and monkeys have been investigated. The initial results would suggest that dysfunction within the prefrontal cortex (principally, dorsolateral prefrontal cortex in monkeys and medial frontal cortex in rats) is a component of these deficits. Because working memory is clearly one cognitive function subserved by frontal cortex (Goldman-Rakic 1987), we have examined the performance of a spatial delayed alternation task by rats after subchronic PCP administration. In this task, rats are required to maneuver through a T-maze to obtain a reward; on the first trial, the rat is rewarded for entering either arm, and on subsequent trials, the re- ward is only given if the rat alternates between entering the two arms (e.g., left-right-left, etc.). Because a delay period is interposed between trials, the rat is required to briefly maintain information regarding the next choice "on-line," thus, requiring the working memory construct. This task is closely linked with the function of the frontal cortex and its dopaminergic innervation (Brozoski et al. 1979; Kolb 1984; Goldman-Rakic 1987; Bubser and Schmidt 1990; Roberts et al. 1994). Longterm PCP administration produces delay-dependent performance impairments on a variable-delay spatial T-maze alternation task (Jentsch et al. 1997b). Because deficits were minimal at short $(0 \mathrm{~s})$ delays and greater at longer delays, these data seem to implicate specific working memory dysfunction.

Another frontal function that contributes to successful performance of the spatial delayed alternation task is response inhibition. Diamond $(1988,1996)$ and Robbins (1996) have both eloquently described a role for response inhibition in delayed response tasks. In these tasks, the subject must simultaneously maintain information about the next choice "on-line" and also inhibit the tendency to make a choice that was previously rewarded but which is no longer appropriate (a "prepotent" response). This cognitive function has been most closely linked with ventrolateral prefrontal cortex based upon lesion studies in nonhuman primates (Iversen and Mishkin 1970; Dias et al. 1996a). As with delayed response, another task with components of response inhibition, motor planning, and working memory, and that is sensitive to frontal lobe lesions is object retrieval/ detour.

The object retrieval/detour task can be used to assess cognitive function in humans or monkeys (Diamond 1988, 1996; Taylor et al. 1990a,b). This task involves the retrieval of a reward from behind a transparent barrier and, thus, requires several frontal lobe functions, including response inhibition (the need to block the prepotent tendency to make a direct reach for the reward through the transparent barrier), motor planning (the formation of a complex motor act for retrieval of the reward), and, perhaps, working memory (the guidance of reaching behavior by memory, knowledge, or representation, rather than simple visual feedback). Thus, ventral and dorsolateral prefrontal, as well as premotor, cortices may contribute to successful task performance.

Frontal involvement in this task is implicated by impaired performance after widespread lesions of frontal lobe (Moll and Kuypers 1977), more specific ablation of the lateral and orbital frontal regions (Dias et al. 1996b), or dorsolateral prefrontal cortex (Diamond and Goldman-Rakic 1985; Diamond 1988, 1996) in monkeys. In contrast, parietal cortical or hippocampal lesions fail to affect object retrieval performance (Diamond and Goldman-Rakic 1985; Diamond et al. 1989; Diamond 1988, 1996). Furthermore, impaired performance of this task 
is exhibited by monkeys after MPTP-induced reductions in dopamine concentrations within the striatal complex (Taylor et al. 1990a,b). Thus, this task seems to measure several constructs (frontal lobe function, response inhibition, working memory, response planning) impaired in schizophrenia.

Monkeys that are repeatedly exposed to PCP are impaired in acquisition and performance of this retrieval task. During the acquisition phase, drug-treated subjects fail to acquire the "reaching strategy" necessary to perform the task, as do frontal-lesioned or MPTP-treated monkeys (Moll and Kuypers 1977; Diamond and Goldman-Rakic 1985; Diamond 1988; Taylor et al. 1990a,b; Dias et al. 1996b). Furthermore, PCP-treated monkeys are disinhibited; they tend to attempt to reach through the transparent barrier to retrieve the reward and are also specifically perseverative in response (Jentsch et al. 1997c). Importantly, performance of the object retrieval/ detour task is impaired in PCP-treated subjects only when monkeys need to negotiate the barrier (and thus inhibit the prepotent response and maintain "on-line" sequences of responses) and not on special trials that require nothing more than visually guided behavior. Furthermore, no motor or motivational deficits have been found using task-related measures in PCP-treated monkeys (Jentsch et al. 1997c). These data suggest that, unlike acute PCP exposure, "cognitive impulsivity," impaired working memory, and perseveration, but not nonspecific effects, are consequences of repeated exposures to PCP.

\section{Conclusions}

These data on the effects of long-term PCP administration on rats and monkeys are suggestive of a more selective cognitive deficit profile than that exhibited by animals treated with a single dose of the drug. The initial evidence seems to suggest that frontal lobe function is particularly affected after long-term treatment and withdrawal. Because schizophrenics show particularly profound and pronounced deficits on tasks linked with frontal lobe function (see below; Fey 1951; Robbins 1990; Goldman-Rakic 1991; Park and Holzman 1992), with spared performance on simple, associative processes, the cognitive consequences of long-term administration may more isomorphically model the frontal lobe deficits associated with schizophrenia.

\section{FRONTAL CORTICAL DYSFUNCTION: RELEVANCE TO THE PCP MODEL}

As noted, the behavioral deficits in schizophrenic patients are strongly reminiscent of frontal lobe dysfunction. Frontal lobe lesions in humans and monkeys are associated with cognitive dysfunction, flattened affect, social withdrawal, impulsivity, and perseveration (Goldman and Rosvold 1970; Fuster 1997; Goldman-Rakic 1987, 1991; Petrides 1996; Robbins 1990, 1996).

Some specific discussion of the characteristic cognitive deficits exhibited by frontal lobe-lesioned subjects is important when interpreting the previously summarized data. Goldman-Rakic, Petrides, Fuster and Robbins have each described working memory deficits following lesions to the frontal lobe, specifically the dorsolateral frontal cortex (Goldman-Rakic 1991; Petrides 1996; Robbins 1996; Fuster 1997). Goldman-Rakic $(1987,1991)$ has postulated that working memory constitutes a generalized function of the anatomical subdivisions of frontal cortex that operate in parallel within distinct domains, and Petrides (1996) has described the function of the midventrolateral frontal cortex as the retrieval of information from long-term memory, and thus, this system would be integral to the function of the working memory system (dorsolateral prefrontal cortex), providing access to memories that must be integrated with incoming sensory information. Along with "on-line" processing systems, Robbins (1996) has further argued for a distributed system within frontal cortex subserving inhibitory response control. Fuster (1997) has also described a motor "planning" function to prefrontal cortex, complementing the on-line processing and self-ordering functions of this brain region.Thus, lesions within frontal lobe would be hypothesized to impair working memory and response inhibition, and this is, indeed, the case (Milner 1963, 1982; Freedman and Oscar-Berman 1986; Petrides and Milner 1982; Verin et al. 1993).

At present, subchronic PCP-treated rats and monkeys seem to exhibit deficits in working memory and inhibitory control. In contrast, relatively simple sensory and associative processes seem preserved. Although schizophrenic patients exhibit cognitive deficits that likely result from dysfunction with temporal and parietal, as well as frontal, cortices (Goldberg and Gold 1995), it remains to be seen whether long-term PCP administration causes a cognitive deficit syndrome that includes extrafrontal dysfunction. As subchronic PCP exposure seems to induce a syndrome of behavioral deficits consistent with frontal cortical dysfunction, it is perhaps most useful to describe long-term PCP administration as a potential model of schizophrenic frontal cortical dysfunction. Nevertheless, PCP clearly exerts pharmacological and neurochemical effects on numerous cortical regions (see below), so dysfunction within extrafrontal cortical regions is likely. Indeed, schizophrenics and ketamine-treated individuals exhibit impaired declarative memory, a dysfunction possibly associated with altered mesial temporal function (Krystal et al. 1994; Malhotra et al. 1996), so it remains to be seen whether chronic PCP treatment leads to deficits within this mnemonic modiality. 


\section{NEUROBIOLOGICAL SUBSTRATES OF PCP/KETAMINE MODELS OF SCHIZOPHRENIA}

As previously described, the effect of PCP to block NMDA receptors supports a hypoglutamatergic hypothesis of schizophrenia. In this section, we review more comprehensively the neurochemical, neuroanatomical, and neurophysiological effects of PCP to develop a hypothetical substrate for impaired cognition in PCP-treated subjects. An understanding of the full effects of PCP is important when constructing a neurobiological hypothesis of schizophrenia.

\section{NEUROCHEMISTRY}

\section{Cortical Dopamine Dysfunction}

Several neurotransmitter systems in frontal lobe modulate cognitive functions, the most well-studied likely being dopamine. In a seminal series of studies, Goldman-Rakic and colleagues observed preferentially high concentrations of dopamine within the primate prefrontal cortex (Brown and Goldman 1977) and showed that large reductions in dopamine (and norepinephrine) concentrations within the dorsolateral prefrontal cortex of the monkey, induced by 6-hydroxydopamine infusion, led to impairments of spatial delayed alternation, a working memory task (Brozoski et al. 1979). These deficits were equivalent to those seen after ablative lesions of this brain region (Goldman et al. 1971). Furthermore, dopamine $\mathrm{D}_{1}$ receptors within prefrontal cortex have been shown to be involved in working memory, because intraprefrontal cortical infusion or systemic administration of specific dopamine $\mathrm{D}_{1}$ receptor antagonists impaired oculomotor or manual spatial delayed response, respectively (Sawaguchi and Goldman-Rakic 1991; Arnsten et al. 1994). In addition, increased dopamine release in monkey prefrontal cortex is specifically associated with performance of spatial delayed alteration, as opposed to performance of a control task (Watanabe et al. 1997). In contrast, performance of an attentional set-shift task, a test of inhibitory control (Dias et al. 1996a, 1997), was improved by dopamine-specific lesions of the lateral frontal cortex in marmosets (Roberts et al. 1994). In addition, as previously discussed, object retrieval/detour, has been shown to be sensitive to MPTP-induced reductions in corticostriatal dopamine levels (Taylor et al. 1990a,b; Schneider and Kovelowski 1990) and is known to be impaired after long-term PCP administration in monkeys (Jentsch et al. 1997c). Thus, dopamine seems to exert a critical neuromodulatory influence on a subset of the cognitive functions of frontal lobe, and thus, it remains possible that dopaminergic dysfunction results in the deficits in animals after subchronic PCP administration. Is it pos- sible that the PCP-induced dysregulation of frontal cortical dopamine transmission contributes to the associated drug-induced frontal cortical dysfunction? Our recent observations support this notion (see below).

As noted above, acute administration of noncompetitive NMDA receptor antagonists is associated with a dramatic activation of dopamine transmission in forebrain (Doherty et al. 1980; Bowers and Hoffman 1984; Deutch et al. 1987; Hertel et al. 1996; Verma and Moghaddam 1996; Jentsch et al. 1997a), and this effect is likely directly implicated in the cognitive dysfunction exhibited by subjects acutely treated with PCP or ketamine (Verma and Moghaddam 1996), because increased dopamine transmission in prefrontal cortex has been reported to impair spatial working memory (Murphy et al. 1996a; Jentsch et al. 1997d). In rodents, an acute dose of PCP seems to augment prefrontal cortical and ventral striatal dopamine transmission; whereas, the dopaminergic innervation of the dorsal striatum is relatively unaffected (Deutch et al. 1987; Jentsch et al. 1997a). In the monkey, we measured marked increases in frontal cortical dopamine utilization in PCP-treated monkeys, but no change was noted in any subcortical region, including the nucleus accumbens (Jentsch et al. 1997a). Acute PCP administration has also been reported to activate serotonergic, glutamatergic, noradrenergic, cholinergic, and neurotensinergic transmission in rodents and monkeys (see below) (Deutch et al. 1987; Hertel et al. 1996; Jentsch et al. 1997a).

Previously, it was suggested that inhibition of dopamine re-uptake was directly implicated in the acute PCP-induced increases in extracellular levels of dopamine in prefrontal cortex and nucleus accumbens (McCullough and Salamone 1992; Steinpreis and Salamone 1993; Hondo et al. 1994); however, several lines of data refute this hypothesis. The activation of dopamine transmission in the prefrontal cortex and nucleus accumbens induced by acute PCP administration is blocked by such agents as ( \pm HA966, prazosin, and clonidine (Mathe et al. 1996; Jentsch et al. 1997a, 1998b), which modulate the firing patterns of dopaminergic neurons within the ventral mesencephalon (Shepard et al. 1996; Grenhoff and Svensson 1989, 1993) and by intraprefrontal cortical administration of tetrodotoxin (Nishijima et al. 1996). Likewise, PCP itself increases the firing rate of dopaminergic neurons (Freedman and Bunney 1984; French 1994). The available data suggest that acute administration of PCP may reduce cortical GABAergic function (Grunze et al. 1994; Yonezawa et al. 1998), disinhibiting glutamatergic transmission in the prefrontal cortex (Moghaddam et al. 1997) and ventral tegmental area (Mathe et al. 1998). This increase in glutamatergic transmission would then stimulate mesocorticolimbic dopaminergic transmission and locomotor behavior (Jentsch et al. 1998d).

Given the effects of acute PCP treatment on dopa- 
mine transmission and the modulation of cognitive function by this transmitter, we examined dopamine transmission after subchronic PCP exposure in rats and monkeys. In stark contrast to the consequences of acute PCP exposure, we found that repeated, intermittent PCP administrations reduce dopamine turnover in the prefrontal cortex of rats and monkeys (Jentsch et al. $1997 b, c)$. Repeated exposures of PCP to rats cause a marked (to approximately $75 \%$ of control levels) and persistent (at least 3 week) reduction in basal, resting dopamine utilization (dihydroxy-O-phenyl-acetic acid [DOPAC]:dopamine ratio) in the medial prefrontal cortex, but not nucleus accumbens or striatum (Jentsch et al. 1997b, 1998c). This effect of PCP seems to be mediated, in part, by NMDA antagonism, because a similar, if smaller, reduction in dopamine transmission in rat prefrontal cortex was noted after subchronic $(+) \mathrm{MK}-$ 801 administration (Jentsch et al. 1998c). In addition, repeated treatment seems to be required because single injection of PCP failed to alter dopamine transmission enduringly in the prefrontal cortex.

The PCP-induced alterations in metabolite:dopamine ratio are caused almost entirely by changes in concentrations of metabolite (Jentsch et al. 1997b,c). The lack of PCP-induced change in tissue concentrations of dopamine, itself, suggests that no direct neurotoxic insult to dopamine neurons occurs during subchronic PCP administration. Presumably, a loss of dopamine neurons would be indicated by a loss of dopamine content in the terminal fields of these projection neurons, but no sign of this is currently apparent. This finding does not rule out the possibility that populations of cells in other regions of the brain, including those that project to prefrontal cortex or the ventral midbrain dopaminergic nuclei, are subject to PCP-induced neurotoxicity.

The effects of long-term PCP exposure in the monkey forebrain are even more profound and anatomically localized. Subchronic PCP treatment enduringly (at least 9 days) reduces dopamine utilization (homovanillic acid [HVA]:dopamine ratio) in several regions of monkey frontal cortex (Jentsch et al. 1997c, 1998e); affected areas include the dorsolateral prefrontal cortex (Walker's area 46), medial prefrontal cortex (area 9), frontal eye fields (area 8A), lateral orbital cortex (area 12 ), infragranular cortex (area 14), and prelimbic (ventromedial limbic frontal) cortex (areas 25/32/33). In contrast, no drug-induced changes are observed in the supplementary motor area (area $6 \mathrm{M}$ ), primary motor cortex (area 4), or rostral frontal pole (area 10). In addition, dopaminergic transmission in other cortical areas (amygdala and entorhinal cortices) and subcortical regions (nucleus accumbens core and shell, caudate nucleus, putamen, septal nucleus, and ventromedial hypothalamus) are unaffected. Thus, the effects are strikingly restricted to frontal cortex. These findings may not be completely analogous to schizophrenia, as Akil and Lewis $(1995,1996)$ have found dopaminergic abnormalities in both frontal and entorhinal cortical areas.

Furthermore, we have recently noted that the extent of dopaminergic inhibition in the dorsolateral prefrontal and prelimbic frontal regions correlates significantly with the degree of performance impairment on the object retrieval/detour task in PCP-treated monkeys (Jentsch et al., 1998e), while successful performance does not correlate with dopamine transmission in other frontal cortical or subcortical brain regions. Likewise, serotonin transmission in any brain region is not significantly related to successful performance of this task. Thus, these data implicate dopaminergic dysfunction with specific frontal regions in the performance of the object retrieval/detour task.

The PCP-induced changes in basal, resting dopamine metabolism are mirrored in the dopaminergic response to stimulation. Acute, mild stress increases dopamine transmission in the rodent prefrontal cortex (Deutch and Roth 1990); however, the dopaminergic response to stress is markedly reduced in the prefrontal cortices of rats that have been subchronically exposed to PCP (Jentsch et al. 1997b). In addition, we have noted that the increase in dopamine release and metabolism induced by an acute PCP challenge is reduced after long-term PCP exposure in rats and monkeys (Jentsch et al. 1997c, 1998f). Thus, it seems that both basal and stimulated dopamine function are reduced by subchronic PCP exposure.

In an attempt to relate these changes in dopamine turnover to transmitter efflux, we have recently examined the effects of long-term PCP treatment on extracellular concentrations of dopamine in rodent prefrontal cortex. A dose regimen that reduces the DOPAC:dopamine ratio in prefrontal cortex (Jentsch et al. 1997b, 1998c) dramatically reduced basal, extracellular dopamine concentrations (to $60 \%$ of control levels) in the prefrontal cortex (Jentsch et al. 1998f).

In contrast, Lindefors et al. (1997) recently reported that repeated administration of ketamine to rats increased basal, resting extracellular levels of dopamine in the prefrontal cortex. Although this finding is seemingly inconsistent with our finding of reduced dopaminergic function after repeated exposures to PCP, several issues concerning this study should be noted. First, Lindefors et al. (1997) used once-daily injections of a relatively moderate dose $(25 \mathrm{mg} / \mathrm{kg})$ of ketamine, a drug with a considerably shorter half-life than that of PCP. This administration regimen would likely be associated with widely oscillating plasma levels of ketamine. In our studies, we generally used twice-daily administration of moderate doses of PCP, a paradigm likely associated (given the longer half-life of $\mathrm{PCP}$ ) with continuously elevated (though waxing and waning) plasma levels of PCP. This pharmacokinetic difference 
may be a critical determining factor in the net effects of drug administration on prefrontal dopamine transmission. Another factor complicating the interpretation of the results of Lindefors et al. (1997) arises from their finding that repeated ketamine administration results in increased basal, resting extracellular concentrations of dopamine, but not DOPAC or HVA, in the prefrontal cortex; however, after repeated ketamine exposures, a single-dose ketamine challenge fails to elevate dopamine efflux beyond the heightened baseline, but increases extracellular DOPAC and HVA. It is difficult to construct a mechanistic hypothesis of how functional changes in neurotransmission, per se, would underlie the specific changes in extracellular dopamine reported by Lindefors et al. (1997).

Thus, it appears that, in contrast to previous speculations (Adams and Moghaddam 1998), dopaminergic function (as measured by in vivo release or ex vivo metabolite measures) is reduced after a dosing regimen of PCP that produces demonstrable frontal cortical cognitive and behavioral deficits in rodents. The neurochemical differences reported highlight the need for examining behavioral and neurobiological function after identical treatments, particularly with regard to pharmacological models.

The reduction in dopamine transmission in the prefrontal cortex of PCP-treated rats and monkeys should be viewed within the context of potential changes in postsynaptic dopamine receptor density. Previously, it was shown that subchronic exposure to MK-801 reduced dopamine $\mathrm{D}_{1}$-receptor mRNA in the rat prefrontal cortex (Healy and Meador-Woodruff 1996a,b). Likewise, in a preliminary study, we have obtained evidence for reduced dopamine $D_{1}$ mRNA levels in the monkey dorsolateral prefrontal cortex after subchronic PCP treatment (Jentsch, Lidow, Roth, and Goldman-Rakic, unpublished observations). These findings suggest that the functional effects of reductions in the synaptic release of dopamine are exacerbated by a loss of a dopamine receptor that seems to be critical to the working memory functions of prefrontal cortex (Sawaguchi and Goldman-Rakic 1991).

The reduction in cortical dopamine transmission (both at the pre- and postsynaptic level) in the chronic PCP model seems to be consistent with some findings in schizophrenic patients. First, the reduction in metabolic activity in the prefrontal cortex of schizophrenic patients is inversely correlated with cerebrospinal fluid concentrations of homovanillic acid, a measure of central dopaminergic transmission (Weinberger et al. 1988). Second, hypofrontality in schizophrenia is alleviated by systemic administration of indirect or direct dopaminergic agonists, such as amphetamine (Daniel et al. 1991) or apomorphine (Daniel et al. 1989; Dolan et al. 1995). Finally, a recent positron emission tomographic (PET) study has suggested that the dopamine $\mathrm{D}_{1}$-recep- tor may be downregulated in schizophrenia (Okubo et al. 1997). Thus, it seems that one component of the cognitive dysfunction of schizophrenia is associated with reduced frontal dopaminergic transmission. This potential biological sequela of the disorder would be consistent with a chronic PCP model of schizophrenia but would be, at face value, inconsistent with an activation of dopamine transmission induced by acute PCP/ketamine administration.

\section{Subcortical Dopamine Dysfunction}

As previously discussed, some effects of acute PCP administration on subcortical dopamine transmission, especially in the nucleus accumbens, of rats have been reported (Doherty et al. 1980; Deutch et al. 1987; Hertel et al. 1996; Jentsch et al. 1997a). In contrast, we failed to find any effect of single-dose PCP exposure on subcortical dopamine utilization in the monkey (Jentsch et al. 1997a). The activation in accumbens dopamine transmission in the rat has been associated with the ability of PCP to stimulate locomotor behavior (McCullough and Salamone 1992; Steinpreis and Salamone 1993; Jentsch et al. 1998d) and may be associated with some psychopathology in PCP-treated humans.

It could be hypothesized that reduced cortical dopamine transmission induced by long-term PCP exposure may be associated with a hyperactivity of subcortical dopamine systems (as with acute administration), because the mesocortical and mesolimbic dopamine systems demonstrate an inverse relationship in animals; that is, hypoactivity of the cortical dopamine system propagates subcortical dopamine hyperactivity (Pycock et al. 1980; Deutch et al. 1990; Grace 1991; Deutch 1992; Roberts et al. 1994). Although no changes in basal, resting dopamine utilization in the nucleus accumbens were noted after subchronic treatment with PCP (Jentsch et al. 1997b,c), we have now found that the mesolimbic dopamine pathway has increased responsivity to haloperidol, d-amphetamine, or mild stress (Jentsch et al. 1998c). Because the dopamine innervation of the striatal complex also seems to be involved in cognitive functioning (Taylor et al. 1990a,b; Schneider and Kovelowski 1990), a dysregulation of the subcortical dopamine system by subchronic PCP exposure might also be related to impaired cognitive function. In fact, Roberts et al. (1994) have previously hypothesized that enhanced attentional set shifting performance after 6-hydroxydopamine lesions of the prefrontal cortex is mediated by subcortical dopaminergic hyperactivity. It is noteworthy in this regard that subcortical dopaminergic function shows the opposite pattern of response to long-term PCP as compared to cortical regions.

Subcortical dopaminergic hyperactivity has also been suggested in schizophrenia (see Davis et al. 1991; Grace 1991; Deutch 1992). Recently, support for this hy- 
pothesis has come from the demonstration that administration of $d$-amphetamine results in an augmented "release" of dopamine within the striatal complex of schizophrenic patients relative to controls (Laruelle et al. 1996; Breier et al. 1997b). These findings are consistent with the original "dopamine hyperactivity" hypothesis of schizophrenia (Carlsson and Lindqvist 1963; Creese et al. 1976), and, taken with our findings of cortical dopaminergic hypoactivity, are consistent with several "revised" dopamine hypotheses of schizophrenia (Carlsson 1988; Davis et al. 1991; Knable and Weinberger 1997). Thus, the chronic PCP model may represent a functional, drug-induced embodiment of the cortical-subcortical dopamine interaction hypothesis of schizophrenia (Robbins, 1990; Grace 1991; Deutch 1992).

\section{Serotonin and Norepinephrine Systems}

Serotonin and norepinephrine dysfunction have also been implicated in schizophrenia (Meltzer 1995; Breier et al. 1998), and norepinephrine, as does dopamine, seems to modulate frontal cortical function (Arnsten and Goldman-Rakic 1985; Arnsten and Jentsch 1997); whereas, little is known about serotonergic effects on prefrontal cortical cognition. Thus, it is perhaps worth restating that no changes in norepinephrine or serotonin metabolism were noted in monkeys or rats, respectively, after long-term PCP treatment (Jentsch et al. $1997 b, c)$. As previously stated, this further implicates a selective change in neurotransmission in the reduced dopamine metabolism after repeated PCP exposures. In contrast to the effects of subchronic exposure, acute administration of PCP clearly augments noradrenergic and serotonergic transmission (Deutch et al. 1987; Jentsch et al. 1997a; Martin et al. 1998). Dysfunction within these systems, then, may be linked to the aberrant behavior of humans and animals acutely exposed to PCP or ketamine.

\section{Glutamatergic and GABAergic Dysfunction}

Alterations in glutamatergic and GABAergic function within prefrontal cortex in schizophrenia have been proposed by a number of researchers (Benes et al. 1991; Akbarian et al. 1995; Selemon et al. 1995; Lewis and Anderson 1995; Bartha et al. 1997; Tamminga 1998). Because these transmitters constitute the "currency" of cortico-cortical circuitry, dysfunction within these systems should result in significantly impaired function of affected cortical regions.

The PCP-ketamine model of schizophrenia, coupled with other findings, became the hallmark of a "hypoglutamatergic" hypothesis of schizophrenia (Javitt and Zukin 1991; Bunney et al. 1994; Tamminga 1998). These ideas are supported by the finding that schizophrenic patients had lower cerebrospinal fluid glutamate concentrations than controls (Kim et al. 1980); however, this finding remains controversial (e.g., Perry, 1982 failed to find such an effect). Furthermore, glutamate receptors have been reported to be increased in schizophrenia (an effect presumably secondary to reduced glutamate transmission; Toru et al. 1994).

Although acute PCP or ketamine administration may be associated with blockade (and net hypoactivity) of the NMDA receptor, the comprehensive effects of these drugs on cortical circuitry are complicated by the finding that acute administration of ketamine or PCP dramatically increases cortical glutamate (and dopamine) efflux (Moghaddam et al. 1997), possibly leading to hyperactivation of non-NMDA glutamate receptors; this hyperactivation of glutamatergic transmission at nonNMDA receptors is a component of Olney and Farber's (1995) "NMDA receptor hypofunction" hypothesis of PCP-induced psychosis. This could also explain the seemingly paradoxical finding that acute ingestion of high doses of PCP, although reducing NMDA-associated transmission, can be proconvulsant (Gorelick and Balster 1994).

Indeed, Moghaddam and colleagues (Moghaddam et al. 1997) have argued that the increase in cortical glutamate efflux after acute NMDA antagonist administration (a net potentiation of transmission at non-NMDA glutamate receptors) produces the increase in dopamine release since intra-cortical administration of an AMPA receptor antagonist blocked the ketamine-induced increase in cortical dopamine release. This is complementary to the finding that injection of the same AMPA antagonist into the cell body regions of the dopamine neurons likewise attenuates PCP-induced biochemical and behavioral abnormalities (Mathe et al. 1998). Thus, increased glutamatergic transmission via non-NMDA/glutamate receptors has been hypothesized to underlie a portion of the PCP-induced behavioral and neurochemical dysfunctions. This concept is not, however, supported by a recent study by Moghaddam and Adams (1998) in which systemic administration of a group II metabotropic glutamate receptor agonist was shown to prevent the PCP-induced augmentation in cortical glutamate release without blocking the increase in cortical dopamine efflux. Moreover, taken together with the result that dopamine receptor antagonism alone ameliorates PCPinduced cognitive dysfunction (Verma and Moghaddam 1996), it appears that cortical glutamate release after NMDA antagonist administration may not be necessary or sufficient to produce altered prefrontal cortical dopamine efflux and associated cognitive deficits.

Further evidence for PCP effects on NMDA and nonNMDA glutamatergic systems comes from the elegant studies of Tamminga and colleagues This group has shown that acute administration of PCP results in biphasic changes in brain glucose metabolism and glutamate receptor density. Studies of the uptake of 2-deoxyglucose in the brains of PCP-treated rats have 
revealed a short-lived (on the order of several hours) increase in forebrain metabolic activity, followed by a longer-lasting reduction in metabolism, which lasts about 2 days (Gao et al., 1993). In addition, NMDA receptor binding in the hippocampus is transiently decreased (at $3 \mathrm{~h}$ ) and subsequently increased (for approximately 2 days) after single-dose PCP administration (Gao and Tamminga 1996). Interestingly, the transient metabolic and glutamatergic effects of PCP are most closely temporally associated with symptom production in ketamine-treated schizophrenic subjects (Lahti et al. 1994) and are consistent with increased limbic blood flow in patients (Lahti et al. 1995). Of course, it is the early effects that are most closely linked with the ketamine-induced psychosis and cognitive impairments, because these effects are largely short-lived (on the order of hours; Krystal et al. 1994).

Schizophrenia also seems to involve a component of GABAergic dysfunction. Morphometric studies have found abnormalities in local circuit neurons within the schizophrenic cingulate cortex (Benes et al. 1991), and this alteration may actually represent increased cell packing density in the absence of changes in GABA neuron number (indicative of reduced neuropil; Selemon et al. 1995). Furthermore, schizophrenic prefrontal cortex may show reduced levels of $\mathrm{GAD}_{67}$, the enzyme responsible for GABA synthesis (Akbarian et al. 1995) and altered axonal terminals of GABAergic chandelier cells (Woo et al. 1998). These data strongly suggest that dysfunction of local circuit neurons, which utilize GABA as a transmitter, is a component of schizophrenic pathophysiology.

The acute PCP/ketamine model of schizophrenia may also incorporate GABAergic dysfunction. In a slice preparation of rat hippocampal CA1 neurons, it has been shown that MK-801 preferentially reduces alvear stimulation-induced long-term potentiation in local-circuit neurons relative to pyramidal cells (Grunze et al 1994), suggesting that the NMDA receptor antagonists preferentially reduce GABAergic transmission. This, indeed, seems to be the case, because, in prefrontal cortex, PCP increases glutamate release (Moghaddam et al. 1997); whereas, profoundly reducing GABA release (Yonezawa et al. 1998). These findings concur with the hypothesis that NMDA receptors primarily regulate the function of local circuit, GABAergic neurons (Olney and Farber 1995).

As previously discussed, the effects of long-term PCP treatment may represent a superior model of schizophrenic frontal lobe dysfunction. Therefore, it is important to understand changes in glutamatergic and GABAergic activity in animals repeatedly treated with PCP. Although little is known about this subject, preliminary evidence suggests that both glutamatergic and GABAergic systems may be dysfunctional in animals subchronically exposed to PCP in a pattern roughly analogous to schizophrenia. In recent studies, Wang and colleagues have recorded from pyramidal cells in the prefrontal cortices of rats that had been subchronically treated with PCP, and this group has found heightened depolarization of pyramidal neurons after the application of exogenous NMDA in the drug-treated rats relative to controls (Arvanov and Wang 1998). One interpretation of these data is that prolonged reduction in glutamatergic transmission in prefrontal cortex of drugtreated rats is associated with an upregulation of NMDA receptors, and thus, the response to exogenous NMDA application is amplified. To confirm this hypothesis, it would be essential to monitor directly extracellular glutamate levels in vivo and to measure the expression of the subunits of the NMDA receptor after long-term PCP treatment. Increased, expression of GluR1 (a subunit of the AMPA receptor) and NMDARI have been shown in rat prefrontal cortex after repeated exposures to (but not acute administration of) PCP (Tomita et al. 1995; Wang et al. 1998) it is also notable that no significant difference in AMPA receptor subunit mRNA levels were observed in either cortical or striatal regions of elderly schizophrenic patients (Healy et al. 1998); whereas, a significant increase in NMDAR1 and NMDAR2A sununit mRNAs were measured in prefrontal cortex of the same subjects (Meador-Woodruff et al. 1997).

As noted above, GABA interneuron dysfunction has been implicated in schizophrenia. Two main pieces of evidence suggest the same in a chronic NMDA receptor antagonist model. First, reduced levels of $\mathrm{GAD}_{67}$, the enzyme responsible for GABA synthesis, were found in the mouse frontal cortex after subchronic MK-801 exposure (Qin et al. 1994), as in schizophrenia. Likewise, long-term exposure to MK-801 has been reported to reduce local circuit inhibition in the CA1 fields enduringly of the rat hippocampus (Grunze et al. 1997). It remains to be seen whether morphometric changes in local circuit neurons akin to those observed in the brains of schizophrenic patients are also observed after subchronic PCP exposure.

\section{Cholinergic Dysfunction}

Another critical neuromodulatory influence on cognitive function is exerted by the ascending acetylcholinergic innervation of the forebrain. Moreover, a hypercholinergic hypothesis of the negative symptoms of schizophrenia has been promoted (Tandon and Greden 1989). Acute administration of PCP to rats seems to increase acetylcholinergic transmission profoundly (as revealed by a hypercholinergic mechanism in the neurotoxic effects of PCP, Olney et al. 1991). In addition, single-dose administration has been observed to increase cortical acetylcholine turnover (Murray and Cheney 1981) and release in the rat (Giovannini et al. 1994; Hutson and Hogg 1996; Dazzi et al. 1998). 
Little is known about the effects of chronic administration of PCP on cholinergic systems. Hsu et al. (1980) showed that an acute administration of PCP increased the activity of the cholinergic synthetic and catabolic enzymes, choline acetyl transferase, and acetylcholinesterase, respectively, and that chronic administration of PCP tended to reduce the ability of a subsequent PCP challenge to activate these enzymes to the same degree as a single-dose PCP challenge. It is important to note, however, that this weak tolerance to these effects of PCP is not necessarily predictive of the functional activity of cholinergic enzymes either under basal or environmentally challenged (e.g., stress) conditions. Further studies of cholinergic transmission after chronic PCP are necessary to elucidate how cholinergic systems may be dysregulated in this animal model.

Recent studies have shown that dopaminergic activation increases cortical acetylcholine release (Day and Fibiger 1992, 1993), and recent studies have suggested that this modulatory effect is mediated by dopamine receptors in the nucleus accumbens (Moore et al. 1998). Because subcortical dopaminergic transmission seems to be augmented after long-term PCP administration, cholinergic hyperactivity in prefrontal cortex may be a consequence of this pharmacological model. On-going studies are directed at assessing this hypothesis.

\section{NEUROANATOMY}

\section{Neurotoxicity of NMDA Receptor Antagonists}

The elegant work of Olney and colleagues (see Olney and Farber 1995 for review) has focused on the neurotoxic effects of "NMDA receptor hypofunction" and the potential implications of this phenomenon for schizophrenia. This group originally reported the critical finding that exposure to noncompetitive NMDA receptor antagonists transiently injured neurons within the retrosplenial cortex of the rat, as revealed by cytoplasmic vacuolization (Olney et al. 1989). In a recent study, Corso et al. (1997) showed that this damage is largely reversible; only after administration of extremely high doses $(50 \mathrm{mg} / \mathrm{kg}$ ) of PCP, does irreversible cell death (demonstrated by agyrophilia) occur. In addition, even after high-dose administration, damage, in most cases, is largely limited to such limbic cortical regions as the retrosplenial, piriform, entorhinal, insular, amygdalar, and hippocampal cortices (Corso et al. 1997). Nevertheless, the transient damage within limbic cortex regions may be associated with the acute neurochemical changes induced by single-dose PCP administration.

At least a component of the acute PCP-induced neurotoxicity may be mediated by hyperactivation of dopaminergic systems. For example, several studies have demonstrated that dopamine receptor antagonists prevent PCP-induced cellular damage (Farber et al. 1993,
1996). In addition, the neurotoxicity is prevented by administration of $\alpha-2$ noradrenergic agonists (Farber et al. 1995), which have been shown to block the PCP-induced increases in forebrain dopamine transmission (Jentsch et al. 1998b). These data suggest that hyperactivation of dopamine transmission may participate in the pathway from single-dose PCP administration to neuronal damage.

Cellular death is more frequently a consequence of repeated exposure to NMDA receptor antagonists. Ellison and colleagues $(1993,1994)$ have shown that chronic administration of high doses $(15 \mathrm{mg} / \mathrm{kg}$ ) of PCP (by means of osmotic minipumps) induced a pattern of neurotoxicity in limbic brain regions similar to those damaged by high-dose, acute PCP administration (Olney et al. 1989; Corso et al. 1997). Because persistent neurotoxicity and spatial learning deficits have been shown in mice treated with a single-, high-dose of MK801 (Wozniak et al. 1996), it is possible that PCPinduced neurotoxicity is a neural substrate of cognitive dysfunction in this putative animal model of psychosis.

\section{ELECTROPHYSIOLOGY}

\section{PCP-Induced Changes in Cortical Gating of Accumbal Neurons}

The groundbreaking work of Grace and colleagues has led to the development of a hypothetical circuit by which hippocampal and amygdalar efferents can modulate or "gate" prefrontal cortical input to nucleus accumbens neurons. Briefly, stimulation of the hippocampus or amygdala significantly facilitates the ability of prefrontal stimulation to result in spiking in accumbal neurons (O'Donnell and Grace 1995; Moore and Grace 1996). Moreover, Moore and Grace (1997) have found that the gating of prefrontal cortical input to accumbens neurons by temporal cortex is significantly reduced, and PCP-induced behaviors are augmented, in a neurodevelopmental model of schizophrenia (prenatal exposure to the mitotoxin methylazoxymethanol acetate). This modulation of frontal cortical afferents to the nucleus accumbens may have relevance for dopaminergic and PCP models of schizophrenia, because dopamine receptor agonists and acute PCP administration both attenuate the temporal cortical gating of prefrontal inputs to the nucleus accumbens (O'Donnell and Grace 1996; Moore and Grace 1996; Grace et al. 1998). This effect of PCP is consistent with mesolimbic dopaminergic activation after acute administration; however, it is not known, at present, how chronic PCP treatment would affect this system. We have demonstrated that hyperresponsivity of the dopaminergic innervation of the nucleus accumbens is a consequence of long-term PCP exposure (Jentsch et al. 1998c); thus, at this level, acute and chronic administration may induce somewhat similar effects. 


\section{SUMMARY}

Several neurochemical and neuroanatomical substrates for altered behavior in PCP-treated animals have been offered. It is unclear, comprehensively, how the activation versus inhibition of dopamine systems induced by acute versus chronic exposure of $\mathrm{PCP}$, respectively, will be incorporated into a final pathophysiological hypothesis of schizophrenia. Nevertheless, it is important to note that PCP can not be argued to support a single "transmitter hypothesis" of schizophrenia. It is perhaps more informative to investigate how individual behavioral alterations may be subserved by particular neurotransmitter dysfunctions.

\section{PCP MODELS OF SCHIZOPHRENIA AND ANTIPSYCHOTIC DRUGS}

The effects of neuroleptic drugs on PCP-induced behavioral and biological effects in humans and animals have been examined with reports of varying results. The modulation of the PCP-induced alterations in dopamine transmission by putative antipsychotic drugs may also prove to be relevant for predicting cognitive response to therapeutic drugs.

\section{Response of PCP Effects to Antipsychotic Drugs}

The effects of antipsychotic drugs on the behavioral and neurobiological consequences of PCP administration in animals and humans have been studied in the hope that this model system would provide predictive information about the efficacy of novel antipsychotic drugs for use in the treatment of schizophrenia and other psychotic disorders. Several biological and behavioral indices predict differential clinical response to typical versus atypical antipsychotic drugs; whereas, others fail to produce similar results.

First, it is important to reflect on the response of NMDA receptor antagonist-induced psychosis in humans to antipsychotic drugs. Several groups have reported moderate effects after administration of typical antipsychotic drugs to PCP-abusing individuals with psychotic symptoms (Castellani et al. 1982; Giannini et al. 1984); whereas, other studies have failed to find such results (Rainey and Crowder 1975; Allen and Young 1978; Bowers et al. 1990). Recently, several groups have examined neuroleptic effects on ketamine-precipitated psychotic episodes in schizophrenic subjects; Lahti et al. (1994) reported that haloperidol was ineffective at attenuating NMDA antagonist-induced symptoms; whereas, Malhotra et al. (1997b) demonstrated that clozapine significantly blunted ketamine-precipitated psychoses. In view of the limited, but positive, data, it is clear that further studies of the response of PCP psychosis to cloz- apine and other atypical antipsychotic drugs are warranted.

Animal studies also seem to suggest that PCP-induced behaviors are preferentially responsive to clozapine. Initial studies were directed at investigating the ability of typical and atypical antipsychotic drugs to affect acute PCP-induced hyperlocomotion, social impairments, and prepulse inhibition deficits in rats. Whereas haloperidol was found to be more effective at blocking amphetamine-induced hyperlocomotion than clozapine, the converse was true for PCP (clozapine more effectively prevented PCP-induced hyperlocomotion than haloperidol, Freed et al. 1980; Maurel-Remy et al. 1995). Furthermore, clozapine has been reported to be more effective than haloperidol at restoring social behavior after PCP administration (Steinpreis et al. 1994; SamsDodd 1996). Finally, although haloperidol clearly failed to restore PCP-induced sensorimotor gating deficits in rats (Swerdlow et al. 1996), clozapine has been reported to prevent the same (Bakshi et al. 1994). Likewise, novel antipsychotic agents, such as olanzapine and Seroquel, were observed to present PCP-induced prepulse inhibition deficits (Bakshi and Geyer 1995; Swerdlow et al. 1996). Both clozapine and haloperidol have been reported to prevent stress-induced cognitive dysfunction in monkeys (Murphy et al. 1996a), an effect mediated by heightened prefrontal cortical dopamine transmission (Murphy et al. 1996b). Finally, we have reported that clozapine partially alleviated cognitive deficits in monkeys repeatedly treated with PCP (Jentsch et al. 1997c). In contrast, we have observed that haloperidol actually exacerbates deficits in subchronic PCP-treated monkeys (Jentsch et al., 1998g). These data, as a group, concur with findings in humans that clozapine is markedly more effective than haloperidol at alleviating ketamine-induced behavioral deficits.

Clozapine and haloperidol may exert differential or similar effects on PCP-induced neurobiological changes, depending upon the phenomenon being studied. Both clozapine and haloperidol, as well as novel antipsychotic drugs, prevent PCP-induced neurotoxicity, although clozapine has been reported to be more effective (Farber et al. 1993, 1996). In addition, the facilitation of striatal neuron firing induced by PCP in awake, behaving animals is reversed by either clozapine or haloperidol (White et al. 1995). Finally, clozapine, but not haloperidol or raclopride, has been reported to alleviate the PCP-induced blockade of responses of pyramidal neurons in rat prefrontal cortex to exogenously applied NMDA (Wang and Liang 1998).

It is informative to consider briefly the neurochemical effects of neuroleptic drugs in the context of PCP models of schizophrenia. Both haloperidol and clozapine block postsynaptic dopamine receptors at therapeutic doses. Haloperidol is a broad-spectrum dopamine receptor antagonist, affecting $\mathrm{D}_{2}$-like (and to a lesser ex- 
tent) $\mathrm{D}_{1}$-like receptors; clozapine shows slightly higher affinity for $\mathrm{D}_{4}$-receptors, with smaller effects on $\mathrm{D}_{1}, \mathrm{D}_{3}$, and $\mathrm{D}_{2}$ subtypes (Seeman 1992; Seeman and Van Tol 1994; Arnt and Skarsfeldt 1998). Both clozapine and haloperidol, given acutely, increase extracellular levels of dopamine in the prefrontal cortex and striatal complex. Acute clozapine treatment preferentially increased prefrontal dopamine release in the rat; whereas, haloperidol preferentially increased striatal dopamine efflux (Moghaddam and Bunney 1990; Pehek et al. 1993; Youngren et al. 1994), and our group has recently observed a similar effect in the monkey (Youngren et al. 1998). Thus, clozapine (at doses that do not potently block $\mathrm{D}_{1}$-like receptors) may actually potentiate transmission at this receptor subtype. Acute administration of atypical neuroleptics has also been observed to potentiate serotonin and noradrenergic transmission (Breier et al. 1994; Hertel et al. 1997), alterations that may contribute to their beneficial effects.

The neurochemical consequences of clozapine and haloperidol administration may have relevance to their cognitive effects in monkeys repeatedly exposed to PCP. We have argued for a relationship between dopaminergic hypofunction in prefrontal cortex and the cognitive deficits in PCP-treated monkeys (Jentsch et al. 1997c, 1998e). Because clozapine may have a net dopamine $\mathrm{D}_{1}$ agonist effect in rats (Salmi and Ahlenius 1996), the beneficial effects of clozapine in this paradigm may be mediated by a relative augmentation of cortical dopamine transmission. On the other hand, haloperidol largely blocks dopamine receptors and only mildly stimulates cortical dopamine release, and this net reduction in dopamine transmission in prefrontal cortex may subserve its inability to reverse the PCPinduced cognitive deficits. Likewise, an augmentation of cortical dopamine transmission may be associated with the ability of clozapine to alleviate schizophrenic negative symptomatology (Kane et al. 1988), which may result, in part, from cortical dopaminergic hypofunction (Davis et al. 1991; Knable and Weinberger 1997). Furthermore, the conflicting findings regarding the cognitive effects of clozapine in schizophrenic patients may be caused by the use of high, therapeutic doses of clozapine, which ultimately occupy a significant percentage of dopamine $D_{1}$-receptors (the primary dopaminereceptor subtype in prefrontal cortex; Lidow and Goldman-Rakic 1994), rendering the increased synaptic dopamine without a postsynaptic target.

\section{LONG-TERM PCP EXPOSURE: FURTHER IMPLICATIONS FOR SCHIZOPHRENIA}

Studies of the pathophysiology implicated by PCP models of schizophrenia, especially in nonhuman primates, may lend considerable understanding to prob- lems related to dopaminergic and cognitive dysfunction in human subjects. Indeed, consideration of the nature of dopaminergic perturbation in the PCP model of schizophrenia, in particular, should provide insights regarding novel treatments for symptom subtypes of this disorder, although selective pharmacological modulation of a cortical hypofunction and subcortical hyperfunction may pose a significant challenge. Nevertheless, information regarding: (1) the selective pharmacological regulation of the heterogeneous, ascending dopamine systems (Deutch and Roth 1990); (2) the distinct distribution of dopamine receptor subtypes in forebrain (e.g., Bergson et al. 1995; Mrzljak et al. 1996); and (3) the functionally distinct properties of these receptor subtypes (e.g., on cognition; Goldman-Rakic et al. 1996) should aid in construction of new strategies.

Application of knowledge regarding the unique sensitivity of the mesoprefrontal dopamine projection to stress and several neurotransmitter influences, such as norepinephrine, acetylcholine, serotonin, and substanceP, (Deutch and Roth 1990) should allow for novel strategies for alleviating cortical dopaminergic hypoactivity. For instance, several recent studies have focused on the ability of nicotine, which activates nicotinic acetylcholine receptors and increases $\mathrm{D}_{1}$ dopaminergic transmission (Nisell et al. 1996, 1997), to alleviate schizophrenic symptomatology (Goff et al. 1992; Adler et al. 1993; Ziedonis and George 1997), including deficits presumably mediated by cortical dysfunction (Olincy et al. 1998). Another receptor that seems selectively to regulate the mesocortical dopamine projection is the serotonin 5-HT2a receptor; M100,907; a selective antagonist of this receptor preferentially increases prefrontal cortical dopamine release (Schmidt and Fadayel 1995), and its clinical antipsychotic efficacy is currently being investigated. Furthermore, clozapine has high affinity for this receptor (Meltzer 1995; Ashby and Wang 1996; Arnt and Skarsfeldt 1998). Drugs such as these, which augment cortical dopamine transmission, may alleviate some components of frontal cortical-associated deficits in the PCP model. Theoretically, if cortical dopaminergic dysfunction propagates subcortical dopamine dysfunction, both phenomenon could be alleviated after cortical dopaminergic augmentation; however, this is unlikely, because striatal dopamine release is under the influence of other brain regions likely dysfunctional in schizophrenia (e.g., the hippocampus, Lipska et al. 1993). Nevertheless, the PCP model may provide a useful experimental paradigm for testing drugs that selectively affect cortical dopamine transmission.

Likewise, selective modulation of subcortical dopamine systems may be amenable to investigation in animals that have been repeatedly treated with PCP. Regulation of mesostriatal dopaminergic transmission at the cell body or terminal level may allow for such specific effects. For example, substance-K receptors have been 
argued to affect subcortical dopamine systems more potently (Deutch and Roth 1990). In addition, dopamine $\mathrm{D}_{3}$-receptors are highly enriched in the ventral striatum (Diaz et al. 1995) and may possess autoreceptorlike functions (Aretha et al. 1995); thus, low doses of a dopamine $\mathrm{D}_{3}$-receptor agonist may preferentially educe mesostriatal dopamine overflow. Indeed, Tamminga and colleagues (1978, 1986; Lahti et al. 1998) have shown that schizophrenic symptomatology is reduced after administration of low ("autoreceptor-preferring") doses of apomorphine or preclamol and have hypothesized that dopamine autoreceptor-preferring agonists may be effective treatments for the positive symptoms of schizophrenia. Hypotheses such as these may be tested, at the preclinical level, in subjects that have undergone long-term PCP treatment.

\section{CONCLUSIONS}

The hypoglutamatergic and hyperdopaminergic hypotheses of schizophrenia have been, in principle, difficult to reconcile. We have argued that dysfunction of multiple neurotransmitter systems, beginning with NMDA receptor antagonism, is likely responsible for the behavioral pathologies exhibited by subjects acutely or repeatedly treated with PCP. The reviews of Javitt and Zukin (1991) and O'Donnell and Grace (1998) reflect this hypothesis as they argue for dysfunction within multiple, interactive brain systems after PCP administration. It seems plausible that the heterogeneous subsets of schizophrenic symptoms result from these multiple neural pathologies. Any hypotheses of schizophrenia based upon dysfunction within single transmitter systems must be considered limited. Instead, an integrative, multisystem hypothesis of schizophrenia is warranted, and, indeed, is supported by this pharmacological model of the disorder. Further investigations of the pathophysiology of PCP-treated subjects (especially after long-term exposure) should provide unparalleled insights regarding the neurobiological basis of both normal and schizophrenic functioning, and, ultimately, provide a context for the design of selective treatments for affected forebrain circuits. Pharmacological modulation of the complex neurochemical dysfunctions of schizophrenia pose the ultimate therapeutic challenge, but the characterization of models of the disorder, such as that induced by long-term PCP administration, may be a fundamental step toward solving this intriguing riddle.

\section{ACKNOWLEDGMENTS}

The authors thank Drs. Holly Moore, Peter Hertel, and Jane R. Taylor for their particularly helpful commentaries on the manuscript and Patricia Goldman-Rakic and Laura Dazzi for insightful discussions. The preparation of this review was supported in part by NIMH grants MH-14092 and MH-57483 to RHR and a grant from the Theodore and Vada Stanley Foundation.

\section{REFERENCES}

Adams B, Moghaddam B (1998): Corticolimbic dopamine neurotransmission is temporally dissociated from the cognitive and locomotor effects of phencyclidine. J Neurosci 18:5545-5554

Adler LE, Hoffer LD, Wiser A, Fredman R (1993): Normalization of auditory physiology by cigarette smoking in schizophrenic patients. Am J Psychiat 150:1856-1861

Aguado L, San Antonio A, Perez L, del Valle R, Gomez J (1994): Effects of the NMDA receptor antagonist ketamine on flavor memory: Conditioned aversion, latent inhibition, and habituation of neophobia. Behav Neural Biol 61:271-281

Akbarian S, Kim JJ, Potkin SG, Hagman JO, Tafazzoli A, Bunney WE Jr, Jones EG (1995): Gene expression for glutamic acid decarboxylase is reduced without loss of neurons of prefrontal cortex of schizophrenics. Arch Gen Psychiat 52:258-266

Akil M, Lewis DA (1995): The catecholaminergic innervation of the human entorhinal cortex: Alterations in schizophrenia. Soc Neurosci Abstr 21:238

Akil M, Lewis DA (1996): Reduced dopamine innervation of the prefrontal cortex in schizophrenia. Soc Neurosci Abstr 22:1679

Allen RM, Young SJ (1978): Phencyclidine-induced psychosis. Am J Psychiat 135:1081-1084

American Psychiatric Association (1989): Treatments of Psychiatric Disorders; A Task Force Report of the American Psychiatric Association, vol 2. Washington, DC, American Psychiatric Association

Andreasen NC, Rezai K, Alliger R, et al. (1992): Hypofrontality in neuroleptic-naive patients and in patients with chronic schizophrenia. Arch Gen Psychiat 49:943-958

Angrist BM, Gershon S (1970): The phenomenology of experimentally induced amphetamine psychosis: Preliminary observations. Biol Psychiat 2:95-107

Angrist B, Peselow E, Rubenstein M, Corwin J, Rotrosen J (1982): Partial improvement in negative schizophrenic symptoms after amphetamine. Psychopharmacol 78: 128-130

Aretha CW, Sinha A, Galloway MP (1995): Dopamine D3preferring ligands act as synthesis modulating autoreceptors. J Pharmacol Exp Ther 274:609-613

Arnsten AFT, Goldman-Rakic PS (1985): $\alpha-2$ adrenergic mechanisms in prefrontal cortex associated with cognitive decline in aged nonhuman primates. Science 230: 1273-1276

Arnsten AFT, Cai JX, Murphy BL, Goldman-Rakic PS (1994): Dopamine $\mathrm{D}_{1}$-receptor mechanism in the cognitive performance of young adult and aged monkeys. Psychopharmacology 116:143-151

Arnsten AFT, Jentsch JD (1997): The $\alpha-1$ agonist, cirazoline, 
impairs spatial working memory performance in aged monkeys. Pharmacol Biochem Behav 58:55-59

Arnt J, Skarsfeldt T (1998): Do novel antipsychotics have similar pharmacological characteristics? A review of the evidence. Neuropsychopharmacology 18:63-101

Arvanov VL, Wang WY (1998): Clozapine, but not haloperidol or raclopride, prevents the functional hyperactivity of NMDA receptors in rat cortical neurons induced by subchronic administration of phencyclidine. Soc Neurosci Abstr 24:1827

Ashby Jr. CR, Wang RY (1996): Pharmacological actions of the atypical antipsychotic drug clozapine: A review. Synapse 24:349-394

Bakshi VP, Swedlow NR, Geyer MA (1994): Clozapine antagonizes phencyclidine-induced deficits in sensorimotor gating of the startle response. J Pharmacol Exp Ther 271:787-794

Bakshi VP, Geyer MA (1995): Antagonism of phencyclidineinduced deficits in prepulse inhibition by the putative atypical antipsychotic drug olanzapine. Psychopharmacology 122:198-201

Bartha R, Williamson PC, Drost DJ, et al. (1997): Measurement of glutamate and glutamine in the medial prefrontal cortex of never-treated schizophrenic patients and healthy controls by proton magnetic resonance spectroscopy. Arch Gen Psychiat 54:959-965

Benes FM, McSparren J, Bird ED, San Giovanni JP, Vincent SL (1991): Deficits in small interneurons in prefrontal and cingulate cortices of schizophrenic and schizoaffective patients. Arch Gen Psychiat 48:996-1001

Bergson C, Mrzljak L, Smiley J, Pappy M, Levenson R, Goldman-Rakic PS (1995): Regional, cellular, and subcellular variations in the distribution of the $\mathrm{D}_{1}$ - and D5-dopamine receptors in primate brain. J Neurosci 15:7821-7836

Bertolino A, Saunders RC, Mattay VS, Bachevalier J, Frank JA, Weinberger DR (1997): Altered development of prefrontal neurons in rhesus monkeys with neonatal mesial temporo-limbic lesions: A proton magnetic resonance spectroscopic imaging study. Cereb Cortex 7:740-748

Bowers MB, Jr, Hoffman FJ (1984): Homovanillic acid in rat caudate and prefrontal cortex following phencyclidine and amphetamine. Psychopharmacology 84:137-138

Bowers MB, Jr, Mazure CM, Nelson JC, Jatlow PI (1990): Psychotogenic drug use and neuroleptic response. Schizophr Bull 16:81-85

Boyce S, Rupniak NMJ, Steventon MJ, Cook G, Iversen SD (1991): Psychomotor activity and cognitive disruption attributable to NMDA, but not sigma, interactions in primates. Behav Brain Res 42:115-121

Braff DL, Grillon C, Geyer MA (1992): Gating and habituation of the startle reflex in schizophrenic patients. Arch Gen Psychiat 49:206-215

Breier A, Buchanan RW, Waltrip RW, Listwak S, Holmes C, Goldstein DS (1994): The effect of clozapine on plasma norepinephrine: Relationship to clinical efficacy. Neuropsychopharmacology 10:1-7

Breier A, Malhotra AK, Pinals DA, Weisenfeld NI, Pickar D (1997a): Association of ketamine-induced psychosis with focal activation of the prefrontal cortex in healthy volunteers. Am J Psychiatry 154:805-811
Breier A, Su TP, Saunders RC, Carson RE, Kolachana BS, de Bartolomeis A, Weinberger DR, Weisenfeld N, Malhotra AK, Eckelman WC, Pickar D (1997b): Schizophrenia is associated with elevated amphetamine-induced synaptic dopamine concentrations: Evidence from a novel positron emission tomography method. Proc Natl Acad Sci USA 94:2569-2574

Breier A, Elman I, Goldstein DS (1998): Norepinephrine and schizophrenia: A new hypothesis for antipsychotic drug action. Adv Pharmacol 42:785-788.

Brown RM, Goldman PS (1977): Catecholamines in neocortex of rhesus monkeys: Regional distribution and ontogenetic development. Brain Res 124:576-580

Brozoski TJ, Brown RM, Rosvold HE, Goldman PS (1979): Cognitive deficit caused by regional depletion of dopamine in prefrontal cortex of rhesus monkey. Science 205:929-931

Bubser M, Schmidt WJ (1990): 6-OHDA lesions of the rat prefrontal cortex increases locomotor activity, impairs acquisition of delayed alternation tasks, but does not affect uninterrupted tasks in the radial maze. Behav Brain Res 37:157-168

Bunney BG, Bunney WE Jr, Carlsson A (1994): Schizophrenia and glutamate. In Bloom FE, Kupfer DJ (eds), Psychopharmacology, The Fourth Generation of Progress. New York, Raven Press, pp 1205-1214

Carlsson A, Lindqvist M (1963): Effect of chlorpromazine or haloperidol on formation of 3-methoxytyramine and normetanephrine in mouse brain. Acta Pharmacol Toxicol 20:140-144

Carlsson A (1988): The current status of the dopamine hypothesis of schizophrenia. Neuropsychopharmacology 1:179-186

Carlsson M, Carlsson A (1989): The NMDA receptor antagonist MK-801 causes marked locomotor stimulation in monoamine-depleted mice. J Neural Transm 75:221-226

Carter CS, Barch D, Cohen JD, Braver TS (1997): CNS catecholamines and cognitive dysfunction in schizophrenia. Schizophr Res 24:211

Castellani S, Giannini AJ, Adams PM (1982): Physostigmine and haloperidol treatment of acute phencyclidine intoxication. Am J Psychiat 139:508-510

Cohen BD, Rosenbaum G, Luby ED, Gottlieb JS (1962): Comparison of phencyclidine hydrochloride (Sernyl) with other drugs. Simulation of schizophrenic performance with phencyclidine hydrochloride (Sernyl), lysergic acid diethylamide (LSD-25), and amobarbital (Amytal) sodium: II. Symbolic and sequential thinking. Arch Gen Psychiat 6:395-401

Corso TD, Sesma MA, Tenkova TI, et al. (1997): Multifocal brain damage induced by phencyclidine is augmented by pilocarpine. Brain Res 752:1-14

Cosgrove J, Newell TG (1991): Recovery of neuropsychological functions during reduction in use of phencyclidine. J Clin Psychol 47:159-169

Courtney SM, Petit L, Maisog JM, Ungerleider LG, Haxby JV (1998): An area specialized for spatial working memory in human frontal cortex. Science 279:1347-1351

Creese I, Burt DR, Snyder SH (1976): Dopamine receptor binding predicts clinical and pharmacological potencies of antischizophrenic drugs. Science 192:481-483 
Daniel DG, Berman KF, Weinberger DR (1989): The effect of apomorphine on regional cerebral blood flow in schizophrenia. J Neuropsychiat 1:377-384

Daniel DG, Weinberger DR, Jones DW, et al. (1991): The effect of amphetamine on regional cerebral blood flow during cognitive activation in schizophrenia. J Neurosci 11:1907-1917

Davies BM, Beech HR (1960): The effect of 1-arylcyclohexylamine (Sernyl) on twelve normal volunteers. J Mental Sci 106:912-924

Davis KL, Kahn RS, Ko G, Davidson M (1991): Dopamine in schizophrenia: A review and reconceptualization. Am J Psychiat 148:1474-1486

Day J, Fibiger HC (1992): Dopaminergic regulation of cortical acetylcholine release. Synapse 12:281-286

Day J, Fibiger HC (1993): Dopaminergic regulation of cortical acetylcholine release: Effects of dopamine receptor agonists. Neurosci 54:643-648

Dazzi L, Jentsch JD, Roth RH (1998): Acute phencyclidine exposure increases acetylcholine and catecholamine release in rat prefrontal cortex in vivo: Modulation by S-(-)HA966 and clonidine. Soc Neurosci Abstr 24:744

Deutch AY, Tam SY, Freeman AS, Bowers Jr MB, Roth RH (1987): Mesolimbic and mesocortical dopamine activation induced by phencyclidine: Contrasting response to striatal response. Eur J Pharmacol 134:257-264

Deutch AY, Clark WA, Roth RH (1990): Prefrontal cortical dopamine depletion enhances the responsiveness of mesolimbic dopamine neurons to stress. Brain Res 521:311-315

Deutch AY, Roth RH (1990): Determinants of stress-induced activation of the prefrontal cortical dopamine system. Prog Brain Res 85:367-403

Deutch AY (1992): The regulation of subcortical dopamine systems by the prefrontal cortex: Interactions of central dopamine systems and the pathogenesis of schizophrenia. J Neural Transm [Gen Sect] 36:61-89

Diamond A, Goldman-Rakic PS (1985): Evidence for involvement on prefrontal cortex in cognitive changes during the first year of life: Comparison of performance of human infants and rhesus monkeys on a detour task with transparent barrier. Soc Neurosci Abstr 11:832

Diamond A (1988): Differences between adult and infant cognition: Is the crucial variable presence or absence of language? In Weiskrantz L (ed), Thought Without Language. New York, Oxford University Press, pp 337-370

Diamond A, Zola-Morgan S, Squire LR (1989): Successful performance by monkeys with lesions of the hippocampal formation on A-B and object retrieval, two tasks that mark developmental changes in human infants. Behav Neurosci 103:526-537

Diamond A (1996): Evidence for the importance of dopamine for prefrontal cortex functions early in life. Phil Tran Roy Soc Lond, B 351:1483-1494

Dias R, Robbins TW, Roberts AC (1996a): Dissociation in prefrontal cortex of affective and attentional shifts. Nature 380:69-72

Dias R, Robbins TW, Roberts AC (1996b): Primate analog of the Wisconsin Card Sorting Test: Effects of excitotoxic lesions of the prefrontal cortex in the marmoset. Behav Neurosci 110:872-886

Dias R, Robbins TW, Roberts AC (1997): Dissociable forms of inhibitory control within prefrontal cortex with an analog of the Wisconsin Card Sort test-Restriction to novel situations and independence from on-line processing. J Neurosci 17:9285-9297

Diaz J, Levesque D, Lammers CH, Griffon N, Martres MP, Schwartz JC, Sokoloff P (1995): Phenotypical characterization of neurons expressing the dopamine $\mathrm{D}_{3}$-receptor in the rat brain. Neuroscience 65:731-745

Dickerson F, Boronow JJ, Ringel N, Parente F (1996): Neurocognitive deficits and social functioning in outpatients with schizophrenia. Schizophr Res 21:75-83

Doherty JD, Simonovic M, So R, Meltzer HY (1980): The effect of phencyclidine on dopamine synthesis and metabolism in rat striatum. Eur J Pharmacol 65:139-149

Dolan RJ, Fletcher P, Frith CD, Friston KJ, Frackowiak RSJ, Grasby PM (1995): Dopaminergic modulation of impaired cognitive activation in the anterior cingulate cortex in schizophrenia. Nature 378:180-182

D'Souza DC, Belger A, Zimmerman L, Adams S, Gil R, Sernyak M, Krystal J (1997): Cannabinoid sensitivity in schizophenia: Dose-response of tetrahydrocannabinol effects in schizophrenics and healthy controls. (Abstr) Am Coll Neuropsychopharmacol 36:286

El-Khodor BF, Boksa P (1997): Long-term reciprocal changes in dopamine levels in prefrontal cortex versus nucleus accumbens in rats born by caesarean section compared to vaginal birth. Exp Neurol 145:118-129

Ellison G, Switzer RC (1993): Dissimilar patterns of degeneration in brain following four different addictive stimulants. Neuroreport 5:17-20

Ellison G (1994): Competitive and noncompetitive NMDA receptor antagonists induce similar limbic degeneration. Neuroreport 5:2688-2692

Ellison G (1995): The N-methyl-D-aspartate antagonists phencyclidine, ketamine, and dizocilpine as both behavioral and anatomical models of the dementias. Brain Res Rev 20:250-267

Everitt BJ, Rogers RD, Baldacchino A, Johnson AJ, Swainson R, London M, Deakin GWF, Robbins TW, Sahakian BJ (1997): Altered decision-making following frontal lesions: A comparison with amphetamine and opiateabusers. Soc Neurosci Abstr 23:495

Farber NB, Price MT, Labruyere J, Nemnich J, St Peter H, Wozniak DF, Olney JW (1993): Antipsychotic drugs block phencyclidine receptor-mediated neurotoxicity. Biol Psychiat 34:119-121

Farber NB, Foster J, Duhan NL, Olney JW (1995): $\alpha-2$ adrenergic agonists prevent MK801 neurotoxicity. Neuropsychopharmacology 12:347-349

Farber NB, Foster J, Duhan NL, Olney JW (1996): Olanzapine and fluperapine mimic clozapine in preventing MK801 neurotoxicity. Schizophr Res 21:33-37

Fey ET (1951): The performance of young schizophrenics and young normals on the Wisconsin Card Sorting Test. J Consult Psychol 15:311-319

Fraser CM, Fisher A, Cooke MJ, Thompson ID, Stone TW (1997): Purine modulation of dizocilpine effects on spontaneous alternation. Psychopharmacology 130:334-342 
Frederick DL, Gillam MP, Allen RR, Paule MG (1995): Acute behavioral effects of phencyclidine on rhesus monkey performance in an operant test battery. Pharmacol Biochem Behav 52:789-797

Freed WJ, Weinberger DR, Bing LA, Wyatt RJ (1980): Neuropharmacological studies of phencyclidine (PCP)induced behavioral stimulation in mice. Psychopharmacology 71:291-297

Freedman AS, Bunney BS (1984): The effects of phencyclidine and $\mathrm{N}$-allyl-normetazocine on midbrain dopamine neuronal activity. Eur J Pharmacol 104:287-293

Freedman M, Oscar-Berman M (1986): Bilateral frontal lobe disease and selective delayed response deficits in humans. Behav Neurosci 100:337-342

French ED (1994): Phencyclidine and the midbrain dopamine system: Electrophysiology and behavior. Neurotoxicol Teratol 16:355-362

Fuster JM (1997): The Prefrontal Cortex: Anatomy, Physiology, and Neuropsychology of the Frontal Lobe, 2nd ed. Philadelphia, Lippincott-Raven

Gao XM, Shirakawa O, Du F, Tamminga CA (1993): Delayed regional metabolic actions of phencyclidine. Eur J Pharmacol 241:7-15

Gao XM, Tamminga CA (1996): Phencyclidine produces changes in NMDA and kainate receptor binding in rat hippocampus over a 48-hour time course. Synapse 23:274-279

Geyer MA, Segal DS, Greenberg BD (1984): Increased startle responding in rats treated with phencyclidine. Neurobehav Toxicol Teratol 6:1-4

Geyer MA, Braff DL (1987): Startle habituation and sensorimotor gating in schizophrenia and related animal models. Schizophr Bull 13:643-668

Geyer MA, Markou A (1994): Animal models of psychiatric disorders. In Bloom FE, Kupfer DJ (eds), Psychopharmacology, The Fourth Generation of Progress. New York, Raven Press, pp 787-798

Giannini AJ, Eighan MS, Loiselle RH, Giannini MC (1984): Comparison of haloperidol and chlorpromazine in the treatment of phencyclidine psychosis. J Clin Pharmacol 24:202-204

Giovannini MG, Mutolo D, Bianchi L, Michelassi A, Pepeu G (1994): NMDA receptor antagonists decreases GABA outflow from the septum and increase acetylcholine outflow from the hippocampus: A microdialysis study. J Neurosci 15:1358-1365

Glazer WM, Charney DS, Heninger GR (1987): Noradrenergic function in schizophrenia. Arch Gen Psychiatry 44:898-904

Goff DC, Henderson DC, Amico E (1992): Cigarette smoking in schizophrenia: Relationship to psychopathology and medication side-effects. Am J Psychiat 149:1189-1194

Goldberg TE, Bigelow LB, Weinberger DR, Daniel DG, Kleinman JE (1991): Cognitive and behavioral effects of coadministration of dextro-amphetamine and haloperidol in schizophrenia. Am J Psychiat 148:78-84

Goldberg TE, Gold JM (1995): Neurocognitive deficits in schizophrenia. In Hirsch SR, Weinberger DR (eds), Schizophrenia. London, Blackwell, pp 146-162

Goldman PS, Rosvold HE (1970): Localization of function within the dorsolateral prefrontal cortex of the rhesus monkey. Exp Neurol 27:291-304

Goldman PS, Rosvold HE, Vest B, Galkin TW (1971): Analysis of the delayed-alternation deficit produced by dorsolateral prefrontal lesions in the rhesus monkey. J Comp Physiol Psychol 77:212-220

Goldman-Rakic PS (1987): Circuitry of the frontal cortex and the regulation of behavior by representational knowledge. In Plum F, Mountcastle VM (eds), Handbook of Physiology, the Nervous System, vol 5. Bethesda, Maryland, American Physiological Society, pp 373-417

Goldman-Rakic PS (1991): Prefrontal cortical dysfunction in schizophrenia: Relevance of working memory. In Carroll BJ, Barrett JE (eds), Psychopathology and the Brain. New York, Raven, pp 1-23

Goldman-Rakic PS, Bergson C, Mrzljak L, Williams GV (1996): Dopamine receptors and cognitive function in nonhuman primates. In Neve KA, Neve RL (eds), The Dopamine Receptors. Tuscon: Humana Press, pp 499522

Goldman-Rakic PS, Selemon LD (1997): Functional and anatomical aspects of prefrontal pathology in schizophrenia. Schizophr Bull 23:437-458

Gorelick DA, Balster RL (1994): Phencyclidine (PCP). In Bloom FE, Kupfer DJ (eds), Psychopharmacology, The Fourth Generation of Progress. New York, Raven Press, pp 1767-1776

Grace AA (1991): Phasic versus tonic dopamine release and the modulation of dopamine system responsivity: A hypothesis for the etiology of schizophrenia. Neuroscience $41: 1-24$

Grace AA, O'Donnell P, Moore H (1998): The modulation of corticoaccumbens transmission by limbic afferents and dopamine: A model for the pathophysiology of schizophrenia. Adv Pharmacol 42:721-724

Grace AA, Moore H (1998): Regulation of information flow in the nucleus accumbens: A model for the pathophysiology of schizophrenia. In Lenzenweger et al. (eds), The Pathogenesis of Schizophrenia: An Experimental Psychopathology Perspective. Washington, DC, American Psychological Association, pp 123-160

Grenhoff J, Svensson TH (1989): Clonidine modulates dopamine cell firing in rat ventral tegmental area. Eur J Pharmacol 165:11-18

Grenhoff J, Svensson TH (1993): Prazosin modulates the firing pattern of dopamine neurons in rat ventral tegmental area. Eur J Pharmacol 233:79-84

Grotta J, Clark W, Coull B, Pettigrew LC, Mackay B, Goldstein LB, Meissner I, Murphy D, LaRue L (1995): Safety and tolerability of the glutamate antagonist CGS 19755 (Selfotel) in patients with acute ischemic stroke. Stroke 26:602-605

Grunze HCR, Rainnie DG, Hasselmo ME, Barkai E, Hearn EF, McCarley RW, Greene RW (1994): NMDA-dependent modulation of CA1 local circuit inhibition. J Neurosci 16:2034-2043

Grunze HCR, Rujescu-Balcu D, Moller HJ, Rainnie D, McCarley RW, Greene RW (1997): Chronic, in vivo administration of low dose MK-801 alters CA1 local circuit inhibition in vitro. Soc Neurosci Abstr 23:2309

Heale V, Harley C (1990): MK-801 and AP-5 impair acquisi- 
tion, but not retention, of the Morris milk maze. Pharmacol Biochem Behav 36:145-149

Healy DJ, Meador-Woodruff JH (1996a): Differential regulation, by MK-801, of dopamine receptor gene expression in rat nigrostriatal and mesocorticolimbic systems. Brain Res 708:38-44

Healy DJ, Meador-Woodruff JH (1996b): Dopamine receptor gene expression in hippocampus is differentially regulated by the NMDA receptor antagonist MK-801. Eur J Pharmacol 306:257-264

Healy DJ, Haroutunian V, Powchik P, Davidson M, Davis KL, Watson SJ, Meador-Woodruff, JH (1998): AMPA receptor binding and subunit mRNA expression in prefrontal cortex and striatum of elderly schizophrenics. Neuropsychopharmacology, in press

Hertel P, Mathe JM, Nomikos GG, Iurlo M, Mathe AA, Svensson TH (1996): Effects of d-amphetamine and phencyclidine on behavior and extracellular concentrations of neurotensin and dopamine in the ventral striatum and medial prefrontal cortex of the rat. Behav Brain Res 72:103-114

Hertel P, Nomikos GG, Schilstrom B, Arborelius L, Svensson TH (1997): Risperidone dose-dependently increases extracellular concentrations of serotonin in the rat frontal cortex: Role of $\alpha-2$ adrenoceptor antagonism. Neuropsychopharmacology 17:44-55

Hertzman M, Reba RC, Kotlyarove EV (1990): Single photon emission computerized tomography in phencyclidine and related drug abuse. Am J Psychiat 147:255-256

Hoehn-Saric R, McLeod DR, Glowa JR (1991): The effects of NMDA receptor blockade on the acquisition of a conditioned emotional response. Biol Psychiat 30:170-176

Hondo H, Yonezawa Y, Nakahara T, Hirano M, Uchimura H, Tashiro N (1994): Effect of phencyclidine on dopamine release in the prefrontal cortex: An in vivo microdialysis study. Brain Res 633:337-342

Hsu LL, Smith RC, Rolsten C, Leelavathi DE (1980): Effects of acute and chronic phencyclidine on neurotransmitter enzymes in rat brain. Biochem Pharmacol 29:2524-2526

Hudzik TJ, Wenger GR (1993): Effects of drugs of abuse and cholinergic agents on delayed matching-to-sample responding in squirrel monkey. J Pharmacol Exp Ther 265:120-127

Hutson PH, Hogg JE (1996): Effects of and interactions between antagonists for different sites on the NMDA receptor complex on hippocampal and striatal acetylcholine efflux in vivo. Eur J Pharmacol 295:45-52

Ingvar DH, Franzen G (1974): Distribution of cerebral activity in chronic schizophrenia. Lancet 2:1484-1486

Itil T, Keskiner A, Kiremitci N, Holden JMC (1967): Effect of phencyclidine in chronic schizophrenics. Can J Psychiat 12:209-212

Iversen SD, Mishkin M (1970): Perseverative intereference in monkeys following selective lesions of the inferior prefrontal convexity. Exp Brain Res 11:376-386

Javitt DC, Zukin SR (1991): Recent advances in the phencyclidine model of schizophrenia. Am J Psychiat 148:13011308

Jentsch JD, Elsworth JD, Redmond DE, Jr, Roth RH (1997a): Phencyclidine increases forebrain monoamine metabo- lism in rats and monkeys: Modulation by the isomers of HA966. J Neurosci 17:1769-1776

Jentsch JD, Tran A, Le D, Youngren KD, Roth RH (1997b): Subchronic phencyclidine administration reduces mesoprefrontal dopamine utilization and impairs prefrontal cortical-dependent cognition in the rat. Neuropsychopharmacology 17:92-99

Jentsch JD, Redmond DE, Jr, Elsworth JD, Taylor JR, Youngren KD, Roth RH (1997c): Enduring cognitive deficits and cortical dopamine dysfunction in monkeys after long-term administration of phencyclidine. Science 277:953-955

Jentsch JD, Andrusiak EA, Tran A, Bowers MB, Jr, Roth RH (1997d): $\Delta^{9}$-Tetrahydrocannabinol increases prefrontal cortical catecholaminergic turnover and impairs spatial working memory in the rat: Blockade of dopaminergic effects by HA966. Neuropsychopharmacology 16:426-432

Jentsch JD, Elsworth JD, Taylor JR, Redmond DE, Jr, Roth RH (1998a): Dysregulation of mesoprefrontal dopamine neurons induced by acute and repeated phencyclidine administration in the nonhuman primate: Implications for schizophrenia. Adv Pharmacol 42:810-814

Jentsch JD, Wise A, Katz Z, Roth RH (1998b): $\alpha$-Noradrenergic modulation of the phencyclidine- and $\Delta 9$-tetrahydrocannabinol-induced increased in dopamine utilization in rat prefrontal cortex. Synapse 28:21-26

Jentsch JD, Taylor JR, Roth RH (1998c): Subchronic phencyclidine administration increases mesolimbic dopamine system responsivity and augments stress- and amphetamine-induced hyperlocomotion. Neuropsychopharmacology 19:105-113

Jentsch JD, Tran A, Taylor JR, Roth RH (1998d): Prefrontal cortical involvement in phencyclidine-induced activation of the mesolimbic dopamine system: Behavioral and neurochemical evidence. Psychopharmacology 138:89-95

Jentsch JD, Taylor JR, Elsworth JD, Redmond DE Jr, Roth RH (1998e): Altered frontal cortical dopaminergic transmission in monkeys after subchronic phencyclidine exposure: Involvement in frontostriatal cognitive deficits. Neurosci, in press

Jentsch JD, Dazzi L, Roth RH (1998f): Subchronic phencyclidine exposure reduces basal dopamine efflux and augments the cholinergic and catecholaminergic response to clozapine. Soc Neurosci Abstr 24:744

Jentsch JD, Taylor JR, Redmond DE Jr, Elsworth JD, Youngren KD, Roth RH (1998g): Reversal of phencyclidineinduced cognitive deficits in monkeys by a selective dopamine D4 receptor antagonist. Psychopharmacol, in press

Jones KW, Bauerle LM, DeNoble VJ (1990): Differential effects of sigma and phencyclidine receptor ligands on learning. Eur J Pharmacol 179:97-102

Jones GH, Marsden CA, Robbins TW (1990): Increased sensitivity to amphetamine and reward-related stimuli following social isolation in rats: Possible disruption of dopamine-dependent mechanisms of the nucleus accumbens. Psychopharmacology 102:364-372

Kane J, Honigfeld G, Singer J, Meltzer HY, Group CC (1988): Clozapine for the treatment-resistant schizophrenic: A double-blind comparison with chlorpromazine. Arch Gen Psychiat 45:789-796 
Kesner RP, Davis M (1993): Phencyclidine disrupts acquisition and retention performance within a spatial continuous recognition memory task. Pharmacol Biochem Behav 44:419-424

Kim JS, Kornhuber HH, Schmid-Burgk W, Holzmuller B (1980): Low cerebrospinal fluid glutamate in schizophrenic patients and a new hypothesis of schizophrenia. Neurosci Lett 20:379-382

Knable MB, Weinberger DR (1997): Dopamine, the prefrontal cortex and schizophrenia. J Psychopharmacol 11:123131

Kolb B (1984): Functions of prefrontal cortex in the rat. Brain Res Rev 8:65-98

Krystal JH, Karper LP, Seibyl JP, Freeman GK, Delaney R, Bremner JD, Heninger GR, Bowers MB Jr, Charney DS (1994): Subanesthetic effects of the noncompetitive NMDA receptor antagonist, ketamine, in humans: Psychotomimetic, perceptual, cognitive, and neuroendrocrine responses. Arch Gen Psychiat 51:199-214

Lahti AC, Koffel B, Laporte D, Tamminga CA (1994): Subanesthetic doses of ketamine stimulate psychosis in schizophrenia. Neuropsychopharmacology 13:9-19

Lahti AC, Holcomb HH, Medoff DR, Tamminga CA (1995): Ketamine activates psychosis and alters limbic blood flow in schizophrenia. Neuroreport 6:869-872

Lahti AC, Weiler MA, Corey PK, Lahti RA, Carlsson A, Tamminga CA (1998): Antipsychotic properties of the partial dopamine agonist (-)-3-(3-hydroxyphenyl)-N-N-propylpiperidine (Preclamol) in schizophrenia. Biol Psychiat 43:2-11

Lannes B, Micheletti G, Warter JM, Kempf E, DiScala G (1991): Behavioral, pharmacological, and biochemical effects of acute and chronic administration of ketamine in the rat. Neurosci Lett 128:177-181

Laruelle M, Abi-Dargham A, Van Dyck C, Gil R, D'Souza CD, Erdos J, McCance E, Rosenblatt W, Fingado C, Zoghbi SS, Baldwin RM, Seibyl JP, Krystal JH, Charney DS, Innis RB (1996): Single photon emission computerized tomography imaging of amphetaine-induced dopamine release in drug-free schizophrenic subjects. Proc Natl Acad Sci USA 93:9235-9240

Levin ED, Wilson W, Rose JE, McEvoy J (1996): Nicotinehaloperidol interactions and cognitive performance in schizophrenics. Neuropsychopharmacol 15:429-436.

Lewis DA, Anderson SA (1995): The functional architecture of the prefrontal cortex and schizophrenia. Psychol Med 25:887-894

Lidow MS, Goldman-Rakic PS (1994): A common action of clozapine, haloperidol, and remoxipride on $\mathrm{D}_{1}$ - and $\mathrm{D}_{2}$ dopamine receptors in the primate cerebral cortex. Proc Natl Acad Sci USA 91:4353-4356

Lieberman JA, Sheitman BB, Kinon BJ (1997): Neurochemical sensitization in the pathophysiology of schizophrenia: Deficits and dysfunction in neuronal regulation and plasticity. Neuropsychopharmacology 17:205-229

Lindefors N, Barati S, O'Connor WT (1997): Differential effects of single and repeated ketamine administration on dopamine, serotonin, and GABA transmission in rat prefrontal cortex. Brain Res 759:202-212

Lipska BK, Jaskiw GE, Weinberger DR (1993): Postpubertal emergence of hyper-responsiveness to stress and to amphetamine after neonatal damage: A potential animal model of schizophrenia. Neuropsychopharmacology 9:67-75

Luby ED, Cohen BD, Rosenbaum G, Gottlieb JS, Kelly R (1959): Study of a new schizophrenic-like drug: Sernyl. Arch Neurol Psychiat 81:363-369

Malhotra AK, Pinals DA, Weingartner H, Sirocco K, Missar CD, Pickar D, Breier A (1996): NMDA receptor function and human cognition: The effects of ketamine in healthy volunteers. Neuropsychopharmacology 14:301-307

Malhotra AK, Pinals DA, Adler CM, Elman I, Clifton A, Pickar D, Breier A (1997a): Ketamine-induced exacerbation of psychotic symptoms and cognitive impairment in neuroleptic-free schizophrenics. Neuropsychopharmacology 17:141-149

Malhotra AK, Adler CM, Kennison SD, Elman I, Pickar D, Breier A (1997b): Clozapine blunts N-methyl-D-aspartate antagonist-induced psychosis: A study with ketamine. Biol Psychiat 42:664-668

Martin P, Carlsson ML, Hjorth S (1998): Systemic PCP treatment elevates brain extracellular 5-HT: A microdialysis study in awake rats. NeuroReport, in press

Mathe JM, Nomikos GG, Hildebrand BE, Hertel P, Svensson TH (1996): Prazosin inhibits MK-801-induced hyperlocomotion and dopamine release in the nucleus accumbens. Eur J Pharmacol 309:1-11

Mathe JM, Nomikos GG, Schilstrom B, Svensson TH (1998): Non-NMDA excitatory amino acid receptors in the ventral tegmental area mediate systemic dizocilpine (MK801 )-induced hyperlocomotion and dopamine release in the nucleus accumbens. J Neurosci Res 51:583-592

Maurel-Remy S, Bervoets K, Millan MJ (1995): Blockade of phencyclidine-induced hyperlocomotion by clozapine and MDL 100,907 in rats reflects antagonism of 5-HT2a receptors. Eur J Pharmacol 280:9-11

McCullough LD, Salamone JD (1992): Increases in extracellular dopamine levels and locomotor activity after direct infusion of phencyclidine into nucleus accumbens. Brain Res 577:1-9

Meador-Woodruff JH, Haroutunian V, Powchick P, Davidson M, David KL, Watson SJ (1997): Abnormal NMDA receptor expression in schizophrenic prefrontal cortex. Abstr Am Coll Neuropsychopharmacol 36:167

Melnick SM, Walsh JS, Clark JP, Ettenberg A (1997): Can the behavioral sensitization to repeated phencyclidine be accounted for by tolerance to the drug's ataxic effects? Soc Neurosci Abstr 23:1093

Meltzer HY (1995): The role of serotonin in schizophrenia and the place of serotonin-dopamine antagonist antipsychotics. J clin Psychopharmacol 15:2-3

Miller RE, Levine JM, Mirsky IA (1973): Effects of psychoactive drugs on nonverbal communication and group social behavior of monkeys. J Pers Soc Psychol 28:396405

Milner B (1963): Effects of different brain lesions on card sorting. Arch Neurol 9:100-110

Milner B (1982): Some cognitive effects of frontal lobe lesions in man. Phil Trans R Soc Lond B 286:211-226

Moerschbaecher JM, Thompson DM (1980): Effects of phen- 
cyclidine, pentobarbital, and d-amphetamine on the acquisition and performance of conditional discriminations in monkeys. Pharmacol Biochem Behav 13:887-894

Moghaddam B, Adams B (1998): Reversal of phencyclidine effects by a group II metabotripic glutamate receptor agonist. Science 281:1349-1352

Moghaddam B, Bunney BS (1990): Acute effects of typical and atypical antipsychotic drugs on the release of dopamine from prefrontal cortex, nucleus accumbens, and striatum of the rat: An in vivo microdialysis study. J Neurochem 54:1755-1760

Moghaddam B, Adams B, Verma A, Daly D (1997): Activation of glutamatergic neurotransmission by ketamine: A novel step in the pathway from NMDA receptor blockade to dopaminergic and cognitive disruptions associated with the prefrontal cortex. J Neurosci 17:2921-2927

Moll L, Kuypers HGJM (1977): Premotor cortical ablations in monkeys: Contralateral changes in visually- guided reaching behavior. Science 198:317-319

Moore H, Grace AA (1996): Interactions between amygdala and prefrontal cortical afferents to the nucleus accumbens and their modulation by dopamine receptor activation. Soc Neurosci Abstr 22:1088

Moore H, Grace AA (1997): Anatomical changes in limbic structures produced by methylazoxymethanol acetate (MAM) during brain development are associated with changes in physiological interactions among afferents to the nucleus accumbens. Soc Neurosci Abstr 23:2378

Moore H, Fadel J, Sarter M, Bruno JP (1998): Role of accumbens and cortical dopamine receptors in the regulation of cortical acetylcholine release. Neuroscience, in press

Mrzljak L, Bergson C, Pappy M, Huff R, Levenson R, Goldman-Rakic PS (1996): Localization of the dopamine $\mathrm{D}_{4^{-}}$ receptor to GABAergic neurons of the primate brain. Nature 381:245-248

Murphy BL, Arnsten AFT, Goldman-Rakic PS, Roth RH (1996a): Increased dopamine turnover in prefrontal cortex impairs spatial working memory in rats and monkeys. Proc Natl Acad Sci USA 93:1325-1329

Murphy BL, Arnsten AFT, Jentsch JD, Roth RH (1996b): Dopamine and spatial working memory in rats and monkeys: Pharmacological reversal of stress-induced impairment. J Neurosci 16:7768-7775

Murray TF, Cheney DL (1981): The effect of phencyclidine on the turnover rate of acetylcholine in various regions of rat brain. J Pharmacol Exp Ther 217:733-737

Murray TK, Ridley RM (1997): The effect of dizocilpine (MK$801)$ on conditional discrimination learning in the rat. Behav Pharmacol 8:383-388

Nisell M, Nomikos GG, Hertel P, Panagis G, Svensson TH (1996): Condition-independent sensitization of locomotor stimulation and mesocortical dopamine release following chronic nicotine treatment in the rat. Synapse 22:369-381

Nisell M, Nomikos GG, Chergui K, Grillner P, Svensson TH (1997): Chronic nicotine enhances basal and nicotineinduced for immunoreactivity preferentially in the medial prefrontal cortex of the rat. Neuropsychopharmacology 17:151-161

Nishijima K, Kashiwa A, Hashimoto A, Iwama H, Umino A,
Nishikawa T (1996): Differential effects of phencyclidine and methamphetamine on dopamine metabolism in rat frontal cortex and striatum as revealed by in vivo dialysis. Synapse 22:304-312

O’Donnell P, Grace AA (1995): Synaptic interaction among excitatory afferents to nucleus accumbens neurons: Hippocampal gating of prefrontal cortical input. J Neurosci 15:3622-3639

O'Donnell P, Grace AA (1996): Hippocampal modulation of cortical throughput in the nucleus accumbens: Modulation by dopamine. Biol Psychiat 39:632

O'Donnell P, Grace AA (1998): Dysfunctions in multiple interrelated systems as the neurobiological bases of schizophrenic symptoms clusters. Schizophr Bull 24: 267-283

Ogura H, Aigner TG (1993): MK-801 impairs recognition memory in rhesus monkeys: Comparison with cholinergic drugs. J Pharmacol Exp Ther 266:60-64

Okubo Y, Suhara T, Suzuki K, Kobayashi K, Inoue O, Terasaki O, Someya Y, Sassa T, Sudo Y, Matsushima E, Iyo M, Tateno Y, Toru M (1997): Decreased prefrontal dopamine $D_{1}$ receptors in schizophrenia revealed by PET. Nature 385:634-636

Olincy A, Ross RG, Young DA, Roath M, Freedman R (1998): Improvements in smooth pursuit eye movements after cigarette smoking in schizophrenic patients. Neuropsychopharmacology 18:175-185

Olney JW, Labruyere J, Price MT (1989): Pathological changes in cerebrocortical neurons by phencyclidine and related drugs. Science 244:1360-1362

Olney JW, Labruyere J, Wang G, Wozniak DF, Price MT, Sesma MA (1991): NMDA receptor antagonist neurotoxicity: Mechanism and prevention. Science 254:15151518

Olney JW, Farber NB (1995): Glutamate receptor dysfunction and schizophrenia. Arch Gen Psychiat 52:998-1007

Pallares MA, Nadal RA, Silvestre JS, Ferre NS (1995): Effects of ketamine, a noncompetitive NMDA receptor antagonist, on the acquisition of the lever-press response in rats. Physiol Behav 57:389-392

Park S, Holzman PS (1992): Schizophrenics show spatial working memory deficits. Arch Gen Psychiat 49:975982

Pearlson GD (1981): Psychiatric and medical syndromes associated with phencyclidine (PCP) abuse. Johns Hopkins Med J 148:25-33

Pehek EA, Meltzer HY, Yamamoto BK (1993): The atypical antipsychotic drug amperozide enhances rat cortical and striatal dopamine efflux. Eur J Pharmacol 240:107109

Perry TL (1982): Normal cerebrospinal fluid and brain glutamate levels in schizophrenia do not support the hypothesis of glutamatergic neuronal dysfunction. Neurosci Lett 28:81-85

Petrides M (1996): Specialized systems for the processing of mnemonic information within the primate frontal cortex. Phil Trans R Soc Lond B 352:1455-1462

Petrides M, Milner B (1982): Deficits on self-ordered tasks after frontal- and temporal-lobe lesions in man. Neuropsychologia 20:249-262 
Post RM, Weiss SR, Pert A (1988): Cocaine-induced behavioral sensitization and kindling: Implications for the emergence of pscyhopathology and seizures. Ann NY Acad Sci 53:292-308

Pycock CJ, Carter CK, Kerwin RW (1980): Effect of 6-hydroxydopamine lesioning of medial prefrontal cortex on neurotransmitter systems in subcortical sites in the rat. J Neurochem 34:91-99

Qin ZH, Zhang SP, Weiss B (1994): Dopaminergic and glutamatergic blocking drugs differentially regulate glutamic acid decarboxylase mRNA in mouse brain. Mol Brain Res 21:293-302

Rainey JM, Jr, Crowder MK (1974): Phencyclidine or ketamine. JAMA 230:824

Rainey JM, Jr, Crowder MK (1975): Prolonged psychosis attributed to phencyclidine: Report of three cases. Am J Psychiat 132:1076-1078

Robbins TW (1990): The case for frontostriatal dysfunction in schizophrenia. Schizophr Bull 16:391-402

Robbins TW (1996): Dissociating executive functions of the prefrontal cortex. Phil Trans R Soc Lond B 351:1463-1471

Roberts AC, DeSalvia MA, Wilkinson LS, Collins P, Muir JL, Eueri HBJ, Robbins TW (1994): 6-Hydroxydopamine lesions of the prefrontal cortex in monkeys enhance performance on an analog of the Wisconsin Card Sort Test: Possible interactions with subcortical dopamine. J Neurosci 14:2531-2544

Robinson E, Becker JB (1986): Enduring changes in brain and behavior produced by chronic amphetamine administration: A review and evaluation of animal models of amphetamine psychosis. Brain Res 396:157-198

Salmi P, Ahlenius S (1996): Further evidence for clozapine as a dopamine $\mathrm{D}_{1}$-receptor agonist. Eur J Pharmacol 307:27-31

Sams-Dodd F (1995): Automation of the social interaction task by a video-tracking system: Behavioral effects of repeated phencyclidine treatment. J Neurosci Meth 59:157-167

Sams-Dodd F (1996): Phencyclidine-induced stereotyped behavior and social isolation in rats: A possible animal model of schizophrenia. Behav Pharmacol 7:3-23

Sawaguchi T, Goldman-Rakic PS (1991): D 1 dopamine receptors in prefrontal cortex: Involvement in working memory. science 251:947-950

Scalzo FM, Holson RR (1992): The ontogeny of behavioral sensitization to phencyclidine. Neurotoxicol Teratol 14:7-14

Schlemmer RF, Davis JM (1983): A comparison of three psychotomimetic-induced models of psychosis in nonhuman primate social colonies. Prog Clin Biol Res 131:33-78

Schmidt CJ, Fadayel GM (1995): The selective 5-HT2a receptor antagonist, MDL100,907, increases dopamine efflux in the prefrontal cortex of the rat. Eur J Pharmacol 273: 273-279

Schneider JS, Kovelowski CJ (1990): Chronic exposure to low doses of MPTP: I. Cognitive deficits in motor asymptomatic monkeys. Brain Res 519:122-128

Seeman P (1992): Dopamine receptor sequences. Therapeutic levels of neuroleptics occupy $\mathrm{D}_{2}$-receptors, clozapine occupies $\mathrm{D}_{4}$. Neuropsychopharmacology 7:261-284
Seeman P, Van Tol HHM (1994): Dopamine receptor pharmacology. TIPS 15:264-270

Selemon LD, Rajkowska G, Goldman-Rakic PS (1995): Abnormally high neuronal density in two widespread areas of the schizophrenic cortex. A morphometric analysis of prefrontal area 9 and occipital area 17. Arch Gen Psychiat 52:805-818

Shepard PD, Connelly ST, Lehmann H, Grobaski KC (1996): Effects of the enantiomers of ( \pm )HA966 on dopamine neurons: An electrophysiological study of a chiral molecule. Eur J Pharmacol 285:79-88

Snyder SH (1980): Phencyclidine. Nature 285:355-356

Snyder SH (1988): Psychotogenic drugs as models of schizophrenia. Neuropsychopharmacology 1:197-199

Steinpreis RE, Salamone JD (1993): The role of nucleus accumbens dopamine in the neurochemical and behavioral effects of PCP: a microdialysis and behavioral study. Brain Res 612:263-270

Steinpreis RE, Sokolowski JD, Papanikolaou A, Salamone JD (1994): The effects of haloperidol and clozapine on PCPand amphetamine-induced suppression of social behavior in the rat. Pharmacol Biochem Behav 47:579-585

Steinpreis RE (1996): The behavioral and neurochemical effects of phencyclidine in humans and animals. Some implications for modeling psychosis. Behav Brain Res 74:45-55

Stevens L, Shapiro M, White NM (1997): Effects of NMDA receptor blockade on behaviors differentially affected by fimbria/fornix and amygldala lesions. Psychobiol 25:109-117

Swerdlow NR, Bakshi VP, Geyer MA (1996): Seroquel restores sensorimotor gating in phencylidine-treated rats. J Pharmacol Exp Ther 279:1290-1299

Tamminga CA (1998): Schizophrenia and glutamatergic transmission. Crit Rev Neurobiol 12:21-36

Tamminga CA, Schaffer MH, Smith RC, Davis JM (1978): Schizophrenic symptoms improve with apomorphine. Science 200:567-568

Tamminga CA, Gotta MD, Thaker GK, Alphs LD, Foster NL (1986): Dopamine agonist treatment of schizophrenia with N-propylnorapomorphine. Arch Gen Psychiat 43:398-402

Tandon R, Greden JF (1989): Cholinergic hyperactivity and negative schizophrenic symptoms. Arch Gen Psychiat 46:745-753

Tang AH, Franklin SR (1983): Acquisition of brightness discrimination in the rat is impaired by opiates with psychotomimetic properties. Pharmacol Biochem Behav 18:873-877

Tang AH, Ho PM (1988): Both competitive and noncompetitive antagonists of N-methyl-D-aspartic acid disrupt brightness discrimination in rats. Eur J Pharmacol 151:143-146

Taylor JR, Elsworth JD, Roth RH, Sladek JR, Redmond Jr DE (1990a): Cognitive and motor deficits in the acquisition of an object retrieval/detour task in MPTP-treated monkeys. Brain 113:617-637

Taylor JR, Roth RH, Sladek JR, Redmond DE, Jr (1990b): Cognitive and motor deficits in the performance of an 
object retrieval/detour task with barrier in monkeys treated with MPTP: Long-term performance and effect of transparency of the barrier. Behav Neurosci 104:564576

Tomita H, Hikiji M, Fujiwara Y, Akiyama K, Otsuki S (1995): Changes in dopamine $\mathrm{D}_{2}$ and GluR-1 glutamate receptor mRNAs in the rat brain after treatment with phencyclidine. Acta Med Okayama 49:61-68

Toru M, Kurumaji A, Ishimaru M (1994): Excitatory amino acids: Implications for psychiatric disorders research. Life Sci 55:1683-1699

Tricklebank MD, Singh L, Oles RH, Preston C, Iverson SD (1989): The behavioral effects of MK801: A comparison with antagonists activing noncompetitively and competitively at the NMDA receptor. Eur J Pharmacol 167:127-135

Verin M, Partiot A, Pillon B, Malapani C, Agid Y, Dubois B (1993): Delayed response tasks and prefrontal lesions in man-Evidence for self-generated patterns of behavior with poor environmental modulation. Neuropsychologia 31:1379-1396

Verma A, Moghaddam B (1996): The role of excitatory amino acids in prefrontal cortex function as assessed by spatial delayed alternation performance in rats: Modulation by dopamine. J Neurosci 16:373-379

Vollenweider FX, Leenders KL, Scharfetter C, Antonini A, Maguire P, Missimer J, Angst J (1997): Metabolic hyperfrontality and psychopathology in the ketamine model of psychosis using positron emission tomography (PET) and $\left[{ }^{18} \mathrm{~F}\right]$ fluorodeoxyglucose. Eur Neuropsychopharmacol 7:9-24

Wang C, Showalter VM, Johnson KM (1998): Chronic phencyclidine treatment produces a selective upregulation of the NMDAR1 receptor subunit mRNA in rat forebrain. Soc Neurosci Abstr 24:1970

Wang RY, Liang X (1998): M100907 and clozapine, but not haloperidol or raclopride, prevent phencyclidine-induced blockade of NMDA responses in pyramidal neurons of the rat medial prefrontal cortical slice. Neuropsychopharmacology 19:74-85

Watanabe M, Kodama T, Hikosaka K (1997): Increase in extracellular dopamine in primate prefrontal cortex during a working memory task. J Neurophysiol 78:27952798

Weinberger DR, Berman KF, Zec RF (1986): Physiologic dysfunction of dorsolateral prefrontal cortex in schizophrenia: I. Regional cerebral blood flow evidence. Arch Gen Psychiat 43:114-125

Weinberger DR, Berman KF, Illowsky BP (1988): Physiologic dysfunction of dorsolateral prefrontal cortex in schizophrenia: III. A new cohort and evidence for a monoaminergic mechanism. Arch Gen Psychiat 45:609-615

Weinberger DR, Berman KF (1996): Prefrontal function in schizophrenia: Confounds and controversies. Phil Tran R Soc Lond B 351:1495-1503

White IM, Flory GS, Hooper KC, Speciale J, Banks DA, Rebec GV (1995): Phencyclidine-induced increases in striatal neuron firing in behaving rats: Reversal by haloperidol and clozapine. J Neural Trans [Gen Sect] 102:99112

Wolf ME, Khansa MR (1991): Repeated administration to MK-801 produces sensitization to its own locomotor stimulant effects but blocks sensitization to amphetamine. Brain Res 562:164-168

Woo TU, Whitehead RE, Melchitzky DS, Lewis DA (1998): A subclass of prefrontal GABA axon terminals are selectively altered in schizophrenia. Proc Natl Acad Sci USA 95:5341-5346

Wozniak DF, Brosnon-Watters G, Nardi A, McEwen M, Corso TD, Olney JW, Fix AS (1996): MK-801 neurotoxicity in male mice: Histologic effects and chronic impairments in spatial learning. Brain Res 707:165-179

Wu JC, Buchsbaum MS, Bunney Jr W (1991): Positron emission tomography study of phencyclidine users as a possible drug model of schizophrenia. Japan J Psychopharmacol 11:47-48

Xu X, Domino EF (1994): Phencyclidine-induced behavioral sensitization. Pharmacol Biochem Behav 47:603-608

Yonezawa Y, Kuroki T, Kawahara T, Tashiro N, Uchimura $H$ (1998): Involvement of $\gamma$-aminobutyric acid neurotransmission in phencyclidine-induced dopamine release in the medial prefrontal cortex. Eur J Pharmacol 341:45-56

Youngren KD, Moghaddam B, Bunney BS, Roth RH (1994): Preferential activation of dopamine overflow in prefrontal cortex produced by chronic clozapine treatment. Neurosci Lett 165:41-44

Youngren KD, Inglis FM, Pivirotto PJ, Jedema HP, Bradberry CW, Goldman-Rakic PS, Roth RH, Moghaddam B (1998): Clozapine preferentially increases dopamine release in the rhesus monkey prefrontal cortex compared with the canidate nucleus. Neuropsychopharmacology, in press

Ziedonis DM, George TP (1997): Schizophrenia and nicotine use: Report of a pilot smoking cessation program and review of neurobiological and clinical issues. Schizophr Bull 23:247-254 